\title{
Converting monospecific into mixed forests: stakeholders' views on ecosystem services in the Black Forest Region
}

\author{
Iulia Almeida ${ }^{1}$, Christine Rösch ${ }^{1}$ and Somidh Saha ${ }^{1}$
}

\begin{abstract}
Converting monospecific into mixed forests can increase forests' resilience against climate change-related extreme events such as droughts and storms. This insight is especially true when the tree species help each other, such as the fir in low mountain regions like the Black Forest, which improves the water supply of the beech through the hydraulic lift. However, the climate change adaptation strategy "mixed forests" impacts ecosystem services (ES) provided by these forests. Although the supply of ES is biophysically wellassessed, there is little knowledge about society's views on ES, neither in terms of supply nor preferences. We aim to close this gap by investigating which ES are prioritized in mixed and monospecific forests of fir and beech at the Black Forest region. We analyzed whether differences depend on the type of forest and the stakeholders' respective interests, and their potential benefits from these services. Making stakeholders' perceptions explicit can facilitate their reflection, enhance knowledge-based and participatory decision making, and realize sustainable forest management strategies. We performed semi-structured interviews and conducted qualitative data analyses with MAXQDA software to investigate the rationale behind stakeholders' perceptions of forests ecosystem services. Our results indicate that despite individual heterogeneities in the perceived importance of ES, there was broad agreement that mixed beechfir forests are superior for providing recreation, water retention, and biodiversity among the cultural, regulating, and supporting ES. Although a minority of stakeholders preferred fir forests to provide timber yield, mixed beech-fir forests are preferred by most of the stakeholders in the long term. This preference is mainly due to the higher adaptation capacity of mixed forests toward climate change impacts and higher flexibility to market demands. We conjecture that there may be public support to convert monospecific to mixed forests in the region of the Black Forest as an effective adaptation strategy for the sustainable supply of ES in the future.
\end{abstract}

Key Words: climate change; ecosystem services; forest conversion; mixed forests; monospecific forests; stakeholders' perceptions

\section{INTRODUCTION}

For millennia, forests have played a crucial role in the development of humankind, being a place of numerous human-environmental interactions. Not only are forests an essential source of food, timber, fuel, and a place for recreation and relaxation, but they also provide intangible benefits on which human well-being depends. These include air quality improvement, water storage, and preservation of biodiversity. Increasing urbanization, industrialization, and population growth, together with climate change impacts, have led to the loss and degradation of vast forest areas, thus endangering forests' capacity to provide these valuable ecosystem services (MA 2005). According to the Millennium Ecosystem Assessment (MA), ecosystem services are defined as the many and varied direct or indirect benefits people obtain from the natural environment (MA 2005). The MA developed a framework to enable the broader public to acknowledge these benefits and categorized ecosystem services into four categories. These include tangible or material benefits such as provisioning services (e.g., food and raw materials such as timber and biomass) and intangible or immaterial benefits. Among the intangible benefits are cultural services (e.g., recreation, relaxation, environmental education, and aesthetic enjoyment), regulating services (e.g., nutrient regulation and climate regulation), and supporting ecosystem properties (i.e., the underlying mechanisms of the ecosystems), such as habitat provision and soil formation (MA 2005).

The protection and analysis of ecosystem services (ES) have gained importance over recent decades, both locally and globally. According to the Sustainable Development Goal No. 15 and the European Union Biodiversity Strategy 2020, ecosystems and their services need to be conserved, restored, enhanced, and used sustainably (United Nations 2015) by establishing infrastructure and restoring at least $15 \%$ of degraded ecosystems (European Commission 2011). This goal should be achieved through mapping and assessing ecosystems and their services at the national and regional levels (Maes et al. 2016).

To protect and enhance ES provided by forests, not only disciplinary scientific research but also transdisciplinary research is needed. For this, it is of utmost importance to engage citizens, politicians, and other stakeholders with an interest or an influence in ES. People individually perceive benefits from nature, depending on their needs, motivations, socio-cultural backgrounds, and the type of use of an ecosystem, among other factors. Therefore, it is crucial to understand how different people perceive these benefits, their priorities, and the heterogeneities and similarities among these perceptions (Tauro et al. 2018). A better understanding of stakeholders' views and perceptions can strongly contribute to developing sustainable environmental and public policies (Jacobs et al. 2016, Pascual et al. 2017, Tauro et al. 2018)

There are various stakeholder groups with a specific interest in the benefits of forests because of the intertwined relations between forests and people. Timber companies, for example, are interested in forests as a timber provision enterprise, while tourism companies are interested in using forests as a place for recreation, relaxation, and cultural experience. Meanwhile, conservation organizations are interested in protecting the biodiversity of forests because these ecosystems provide habitats for different species of plants and animals. However, not all types of forests 
offer the same range of ES. The kind of forest management can strongly influence the quality and scope of ES in forests. For instance, in production-oriented monospecific forests, preference is given to provisioning ES, such as timber production.

Scientific literature provides evidence that mixed forests offer a broader range of ES (Nadrowski et al. 2010, Gamfeldt et al. 2013, Pretzsch 2013, Sprauer and Nagel 2015, Thurm and Pretzsch 2016) compared to monospecific forests. Forests with higher species richness at the tree level generally show higher productivity and provide more ES than those with lower species diversity (Thompson et al. 2009, Nadrowski et al. 2010, Morin et al. 2011). Higher primary productivity is linked, for instance, to a higher capacity of forests to sequester carbon and thus mitigate the impacts of climate change (Nadrowski et al. 2010). Moreover, Gamfeldt et al. (2013) showed that species-rich forests have positive relationships with various ES, including biomass production, carbon storage, the supply of berries, and game stock.

Besides providing a more comprehensive range of ES, increasing the share of mixed forests is also considered to be a climate change adaptation strategy, as these forests are believed to better cope with extreme events caused by climate change (Bodin and Wiman 2007, Milad et al. 2013, Brang et al. 2014). Therefore, in Germany, monospecific forests are being gradually converted into mixed forests (Polley et al. 2014). However, stakeholders may perceive that not every ES will benefit equally from converting monospecific forest stands into mixed stands. The stakeholders' awareness of climate change is one of the factors influencing their views on forests and their ES (Sousa-Silva et al. 2018). Previous research undertaken by us has shown a preference for mixedspecies stands because of their higher ES provision compared to monospecific forests in the Black Forest region (Almeida et al. 2018). That research was based on quantitative analysis of an online survey (520 responses) on the public's perceptions on ecosystem services from mixed and monospecific forests of fir and beech. The reasons why specific ES were perceived as better provided in mixed or monospecific forests were not assessed in that study, which incentivized us to analyze the reasons and motivations behind stakeholders' perceptions and choices using qualitative interviews. The Black Forest is a particularly vulnerable area to climate change-related extreme events, especially increasing droughts and storms (Gregow et al. 2017, Meining et al. 2019). Thus we believe that stakeholders' views are converging toward a preference for mixed forests because of an existing climate change awareness and the belief that mixed forests could cope better with threats of climate change.

Making stakeholders' perceptions of ES explicit by analyzing stakeholders' interests and views is a crucial scientific task to provide meaningful insights for decision makers (Martín-López et al. 2012, Plieninger et al. 2013). So far, however, stakeholders' perceptions of ES provided by forests have not been extensively studied. Most existing studies use quantitative analysis (see Carnol et al. 2014, Grilli et al. 2016, Almeida et al. 2018) or relate mainly to specific ES (Edwards et al. 2012, Plieninger et al. 2013, and Lyytimäki and Pitkänen 2020) and only a few applied qualitative analysis (Tauro et al. 2018). This work aimed to assess the perceptions and preferences of stakeholders about ES provided by mixed and monospecific forests of fir and beech in the Black Forest. Specifically, we investigated which ES are prioritized by stakeholders, the underlying reasons behind their selection, and if these ES are better provided in mixed or monospecific forests of fir and beech. Moreover, we identified common and divergent attitudes between and within stakeholder groups.

\section{METHODS}

\section{Selection of the study region}

The selected study region is the Black Forest, Germany's major low mountain range (highest peak $1493 \mathrm{~m}$ ) forest located in the southwest of Germany and the largest share of the forest in the Federal State of Baden-Württemberg. The Black Forest was shaped by a mixed forest landscape dominated by European beech (Fagus sylvatica L.) and silver fir (Abies alba Mil.) until the middle age above the elevation $500 \mathrm{~m}$. However, the industrial revolution, expansion of agriculture, and wars contributed to the significant degradation of forests. Extensive tree planting and forest restoration activities were initiated at the end of the 18th to 19th century. The fast-growing conifers such as Scots pine (Pinus sylvestris L.) and Norway spruce (Picea abies (L.) H. Karst were used in restoration programs instead of European beech and silver fir (ForstBW [date unknown], Ludemann 2005). The plantation of Norway spruce and Scots pine accelerated further after the First and Second World Wars to tackle timber shortage. The frequency and magnitudes of droughts and winter storms increased significantly since the 1950 s in southwest Germany, which resulted in the premature death of Norway spruce and Scots Pine trees. Therefore, two decades ago, federal and state governments have gradually converted conifer monocultures in the Black Forest region to near-natural mixed forests, i.e., forest conversion or Waldumbau in German, to increase the resilience of forests to climate change impacts. For instance, there is evidence that the mixture of these species is more resilient to climate change, as the hydraulic lift of water by fir trees helps neighboring beech trees to survive during drought periods (Schwarzand Bauhus 2019). A research project, named "Potential of beech-fir mixed forests to adapt from the climate change impacts in commercial forests (acronym: BuTaKli)" was launched and funded by the Forest Climate Fund of the German Federal Ministry of Food and Agriculture in 2016. This research article is the outcome of this project. We have focused on the suitability of native and once-abundant beech and fir forests in provisioning multiple ecosystem services. Both types of forests, mixed and monospecific forests of fir and beech, are currently managed in a sustainable way and are used for multiple purposes, including timber production, recreation, and the enhancement of ecosystem services and biodiversity. Today, silver fir and beech trees in forest cover constitute $8 \%$ and $22 \%$ in the Black Forest, respectively (Thünen Institut 2012). The most abundant combination of species in the region are forests of spruce, fir, and beech. Smaller areas are also represented by mixtures of oak, pine, and spruce (ForstBW [date unknown]).

Because it is expected that the average temperature will rise significantly (Endler and Matzarakis 2011), the Black Forest region, with its high proportion of spruce forests, is particularly vulnerable to climate change impacts (Meining et al. 2019). Climate change will affect the ecosystem services provided by forest ecosystems and the value-added and employment in the region because the forestry sector in the state of Baden- 
Württemberg comprises a total of 240,000 forest owners and a forest area of 1.4 million hectares (SDW 2019).

\section{Mapping and identification of relevant stakeholders}

For selecting relevant stakeholders to participate as interview partners, we agreed on a shared understanding of the term "stakeholder," which has several definitions in the literature depending on the context (Reed et al. 2009, Grilli et al. 2016). We decided to follow the definition by Freeman (1984), that stakeholders are those who influence or are affected by a decision or action and who have the power to shape the outcome of these actions. We contextualized this definition for our research topic as follows: a stakeholder is any group or organization that has an "interest" and an "influence or power" on ecosystem services provided by the Black Forest and can contribute to or is affected by the conversion from monospecific to mixed forests because of associated consequences for the environment, landscape, society, and economics. Following this definition, we applied the stakeholder power-interest method to identify and classify relevant stakeholders for engagement in our research project as interview partners, according to the normative approach by Reed et al. (2009). The stakeholders had to be located in the Black Forest region.

We conducted a literature review and used expert knowledge (deductive approach) to identify relevant stakeholders and classified them according to their degree of "power or influence" and "interest" using the interest-power grid approach (Pastowski 2004; S. Mos, 2019 blog, https://medium.com/@soniamos/ stakeholderanalyse-in-3-schritten-interessengruppen-identifizierenund-bewerten-2-3-b156e4090639). We defined "interest" in a rather broad understanding as either being interested in the topic of our project or likely to be affected by its impacts on ES, which could be related to forest management or the transformation of forests to increase forests' resilience. The stakeholder's "interest" can be manifested either by having employment related to forest management, forest conservation, or being active in some organization or association related to forests and the ES they provide. We did not distinguish between economic and noneconomic interests nor between short or long-term interests because of uncertainties to the impacts of climate change on the ecosystem services of forests. The stakeholders' power was defined by the ability to influence decision-making processes concerning forest management and forest policies through stakeholders' right of participation and by giving recommendations. The power interest grid (see Fig. 1) displays the relevant stakeholder groups according to their degree of interest and power in forest ecosystems and their ES.

We followed the results of our power-interest grid to select single stakeholders within each stakeholder group for the interviews. Because mixed fir and beech forests addressed in the research topic are specifically tailored to the conditions in the Black Forest region, we selected only stakeholders who are located or active in the same area. We identified 40 relevant stakeholders belonging to the identified stakeholder groups with high interest and power to invite to an interview, presumably. We carried out internet and social media research and used snowball sampling for collecting the stakeholders' contact information. Of the 40 stakeholders contacted, 20 agreed to be interviewed. For a balanced compilation of stakeholder views, we selected at least two stakeholders for each stakeholder group. We reclassified our stakeholders into six stakeholder groups, as listed in Table 1, instead of the originally planned eight stakeholder groups, for two reasons. First, we merged the stakeholder groups NGOs and governmental nature protection agencies (NPAs), because both groups have a shared interest in the conservation of nature and biodiversity of forests. In addition, we did not get interviews with other NPAs. Second, we did not get interview partners from the timber industry. In the following, the role and function of each stakeholder group is described.

Fig. 1. Power-interest grid showing the degree of interest and power of stakeholders on forest ecosystem services in monospecific and mixed forests in the Black Forest region.

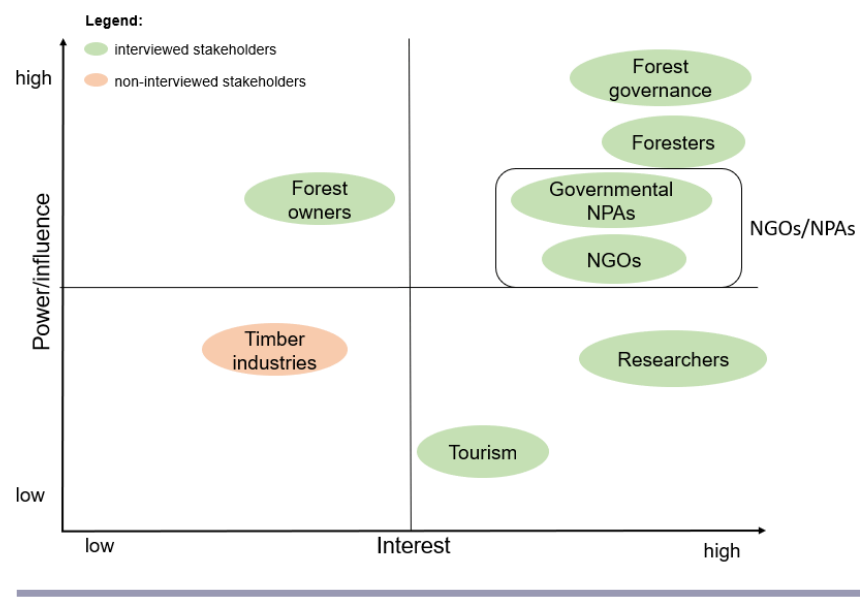

Forest governance, management, and administration (1)

In the Black Forest region, forest management was for a long time shaped by a traditional expert-based approach, with timber production as a primary focus. A small group of actors belonging to the forest sector, mainly the state forest service, private forest owners, and professional forestry organizations, made forest planning decisions (Maier et al. 2014). This has changed over time because of engagement from civil society groups and citizens who demanded a more comprehensive participatory approach, which prioritizes timber production interests and considers the ecological and social values of the forests. As a result, close to nature forest management, initially introduced in Germany in the 1920s, has become popular in the state of Baden-Württemberg in the last decades. Today, forest management and administration offices are more interested in multifunctional forest management and developing adaptation strategies to cope with climate change impacts through close to nature forest management (Brang et al. 2014).

This group comprises the head of a city forest (P1), the representative of a regional forest educational institution $(\mathrm{P} 2)$, a representative of a regional forestry council (P3), and a head of a forest district (P4; Table 1, Stakeholder group 1). Forest state administrations have a high interest in forests and their ES, and influence forest management and conversion processes. They are responsible for managing the forest so that both sustainable timber production and the ecological and social benefits of the forest are guaranteed. It is in their interests that all ES of the 
Table 1. List of the 20 stakeholders interviewed.

\begin{tabular}{|c|c|c|}
\hline Stakeholder Group & Stakeholders (Individuals/Organizations) & Code \\
\hline \multirow{4}{*}{$\begin{array}{l}\text { 1. Forest governance, management, and } \\
\text { administration }(\mathrm{P})\end{array}$} & The head of city forest (Stadtwald in German) in one of the cities in the Black Forest region & P1 \\
\hline & Regional forest education institution/Regional forestry administration & $\mathrm{P} 2$ \\
\hline & Regional council of a city in the Black Forest, a representative in forest-related topics & P3 \\
\hline & $\begin{array}{l}\text { The head of forest district (Kreisforstamt in German) of one of the districts in the Black } \\
\text { Forest region }\end{array}$ & P4 \\
\hline \multirow[t]{3}{*}{ 2. Foresters $(\mathrm{F})$} & County Forest Officer of a state forest & F1 \\
\hline & Forester of a community forest & $\mathrm{F} 2$ \\
\hline & Forester of community forests (4 communities) & F3 \\
\hline \multirow[t]{3}{*}{ 3. Private forest owners/ managers (B) } & Private forest owner (small-scale, size of the forest: 228 ha) & B1 \\
\hline & $\begin{array}{l}\text { Private forest owner's association: marketing and sale of wood that communities and private } \\
\text { forests own }\end{array}$ & B2 \\
\hline & $\begin{array}{l}\text { Private forest manager (large-scale, size of forest in total: } 24,000 \text {. Size of forest in the Black } \\
\text { Forest region: } 12,000 \mathrm{ha} \text { ) }\end{array}$ & B3 \\
\hline \multirow{5}{*}{$\begin{array}{l}\text { 4. Governmental nature protection agencies } \\
\text { (NPAs) and non-governmental } \\
\text { organizations (NGOs; N) }\end{array}$} & $\begin{array}{l}\text { Biosphere reserve in the Black Forest, led by the regional council of a city in the Black Forest } \\
\text { (NPA) }\end{array}$ & N1 \\
\hline & Association for natural history and nature conservation (NGO) & $\mathrm{N} 2$ \\
\hline & Institute for nature protection and landscape ecology. Sponsored by the Nature and & N3 \\
\hline & $\begin{array}{l}\text { Biodiversity Conservation Union of Germany (Landesverband Baden-Württemberg e.V. - } \\
N A B U \text { in German; NGO) }\end{array}$ & \\
\hline & Nature protection foundation: representative of the forestry department (NGO) & N4 \\
\hline \multirow{4}{*}{$\begin{array}{l}\text { 5. Researchers in topics related to forests } \\
\text { and forest management }(\mathrm{R})\end{array}$} & Forest research institute: Expert in forest growth & $\mathrm{R} 1$ \\
\hline & Forest research institute: expert in topics related to forests and society & $\mathrm{R} 2$ \\
\hline & Consulting company for forests and open landscapes & R3 \\
\hline & University department on forest growth and botany: expert in silviculture & R4 \\
\hline \multirow[t]{2}{*}{ 6. Tourism and recreation $(\mathrm{T})$} & Black Forest recreation association & $\mathrm{T} 1$ \\
\hline & Black Forest tourism company & $\mathrm{T} 2$ \\
\hline
\end{tabular}

forests are maintained for current and future generations. They have executive and enforcement power given to them as per the forest law. The city forestry offices are the independent administrative authority of the municipalities and responsible for the following tasks: (1) monitoring in compliance with the forest legal regulations, (2) sustainable forest management to guarantee both renewable production of timber and ecological and social services of the forest, (3) to provide training to future foresters and forest workers (Stadt Freiburg 2013).

Foresters (2)

This group is formed by a county forest officer of a state-owned forest (F1) and two foresters of community forests (F2, F3; Table 1, stakeholder group 2). Foresters manage forests as per the management plan, under the leadership of state and community forest administrations. For example, they are involved in various activities, including the demarcation of the management unit, selection of trees for harvesting, execution of sustainable timber harvesting, forest regeneration and tree planting, aesthetics and forest recreation, and the enforcement of hunting regulations, among others. They have executive and enforcement power given to them by forest laws. They can take decisions over their forest district. They contribute to creating a forest management plan but do not have the power to take decisions at the policy level on forest management at a larger scale.

Forest owners (3)

This group comprises one small-scale forest owner (B1), one largescale forest manager (B3), and the representative of a forest owner's association (B2; Table 1, stakeholder group 3). Nearly
$36 \%$ of the forest area of Baden-Württemberg is privately owned. Around 260,000 private forest owners hold the second-largest share of forests and are primarily organized in forest associations to manage their forests (SDW 2019). Therefore, forest owners represent an important stakeholder group with a strong influence on forestry decision makers. They form part of forest owners' associations and have direct communication with forest rangers and forest administration.

Moreover, forest owners have been historically included in participatory processes regarding forest policy and management (Maier et al. 2014). Their interest in forest management is drawn particularly to timber and biomass production in their forest because timber is a significant income source. Because of their particular interest in provisioning ES, such as timber yield, their interest in forests and all ES categories is mapped as lower than the first three groups above.

\section{Governmental nature protection agencies (NPAs) and nature} protection NGOs (4)

This group is a combination of Governmental NPAs and NGOs. Despite the different organization levels and influence levels of NPAs and NGOs, both groups are interested in nature conservation, particularly in preserving forest areas. Hence, for them, the protection of supporting and regulating ES are a priority over provisioning ES, such as timber production.

\section{Governmental NPA (4a)}

Besides its historical importance for timber production, the Black Forest region is highly attractive for tourists in Germany, and one 
of the reasons is nature protection (Maier et al. 2014). There are various nature protection areas with different protection levels in the region, such as the Black Forest National Park, the Black Forest Nature Park, the Mid and North Black Forest Nature Park, and the Black Forest Biosphere Reserve (LUBW 2020a, Nationalpark Schwarzwald [date unknown]). The Black Forest Biosphere reserve (N1), led by the Regional Council of Freiburg, a city in the Black Forest region, represents this subgroup and sees itself as a model region in which the coexistence of man and nature is developed and promoted. The goal of the reserve is to achieve a balanced relationship between human use and natural cycles, which at the same time contributes to regional value creation (Biosphärengebiet Schwarzwald 2021; see Table 1, stakeholder group 4).

\section{Nature protection NGOs (4b)}

The state of Baden-Württemberg has become a pioneer regarding stakeholder and civil society participation within Germany. Since the late 1990s, forest policy-making processes have increasingly opened up to environmentalists, nature protection, and other civil society groups, promoting communication and information exchange among stakeholders and between policy decision makers (Maier et al. 2014). Therefore, the representatives of regional nature protection NGOs are among the relevant stakeholders for this research. NGOs are defined by the United Nations Department of Public Information (as cited in Leverty 2008) as 'a not-for-profit, voluntary citizens' group that is organized on a local, national or international level to address issues in support of the public good." We defined nature protection NGOs as NGOs that strive for progressive change favoring nature and the environment. The role of nature protection NGOs in the Black Forest region is to promote social transformation toward more sustainable use of natural resources, such as forests and biodiversity protection. They are in charge of protecting and improving biodiversity in forests, contributing to improved thinking, and influencing forest and environmental policy decision-making processes. This works through a welldeveloped network of supporting members and donors and mobilizing large groups of citizens via social networking and actions, such as demonstrations, funding actions, and information and communication campaigns. The NGOs subgroup comprises an association for natural history and nature conservation (N2), an institute for nature protection and landscape ecology (N3), and a nature protection foundation (N4).

\section{Researchers (5)}

Researchers investigating or working on forestry-related topics are highly interested in forests and their ES. However, their influence is limited to producing and disseminating knowledge via publications, lectures, or consultancy. Depending on the research, participatory processes can take place led by a researcher. Indirectly, this knowledge can influence policy makers, who can change or develop new forest management strategies to support ES. This group is formed by a researcher in forest growth (R1), an expert in topics related to forests and society (R2), the representative of a consulting company for forests and open landscapes (R3), and a researcher and expert in silviculture working in a forestry university department (R4).

\section{Tourism and recreation ( 6 )}

The Black Forest area is one of Germany's most popular and visited areas and attracts many tourists (Endler et al. 2010). About
8.9 million visitors were recorded in 2019 (Schwarzwald Tourismus GmbH 2020). Hiking, mountain biking, skiing, and horse riding are some of the many activities offered in the region. The various associations and companies working in these sectors are particularly interested in cultural benefits provided by forests, including the recreation potential, aesthetic value, and forests' scenery. However, they do not have a strong influence on forest management. The representatives of a Black Forest tourism company (T2) and a Black Forest recreation association (T1) are part of this stakeholder group. The former is an umbrella organization representing other recreation associations of the region, and its primary role is the maintenance, signposting, and marking of hiking trails in the forest. Additional tasks are nature conservation and recreation activities for young people and families (Schwarzwaldverein e.V. [date unknown]). These stakeholders are committed at the political level and could influence forest management via lobby. However, they are not directly involved in decision-making processes. Therefore, they are considered as having lower power in the stakeholder-power interest grid.

\section{Timber industry (7)}

The Black Forest region is an important producer and user of wood. Seventy-five percent of the wood felled in BadenWürttemberg is processed in the area. Around 65\% goes to the sawing industry, which is the most important buyer and recycler of wood in the region (LUBW 2020b). Moreover, large sawmill companies are located in the Black Forest region. According to the General Office for Environment of Baden-Württemberg, LUBW (in German: Landesanstalt für Umwelt BadenWürttemberg), sawmills and other processing wood industries are directly affected by climate change (LUBW 2020b).

In general, timber industries are considered a relevant stakeholder in forests. However, in the context of our research topic, the ecosystem services, we assumed that they have less interest and relatively low power to influence decision-making processes. Their interest is in wood only as a product. They do not have long-term purchase contracts to determine which tree species are being established. However, the timber industry is indirectly affected by changes in forest management practices. For this reason, we contacted them and asked them for an interview to assess their opinion of mixed and monospecific forests of fir and beech. We tried to get an interview partner, but we did not get an interview within the desired time window. The stakeholders from the timber industries we contacted did not show particular interest in our research topic. That could be because of their business-oriented focus and their limited interest in ES beyond timber production. Hence, we think the power-interest grid evaluation for the timber industry is reasonable. However, we believe that the timber industry should be pursued to join dialogues on ecosystem services in further research projects as their commercial interests can adapt over time because of the impacts of climate change (Reed et al. 2009).

\section{Development of an interview guideline}

To analyze the views and perceptions of the 20 stakeholders, we performed semi-structured in-depth interviews (Rowley 2012). These kinds of interviews are helpful when investigating a specifically defined phenomenon and can produce reasonably focused data with significant depth (Reed et al. 2009). Before conducting the interviews, we developed a scripted guideline to 
direct the conversation toward the topics and issues of our research and be prepared about how to pose our questions and follow-ups. We tested the interview guideline with an expert in qualitative data analysis to assure that the questions are understandable and estimate the time needed to answer the questions.

We first contacted the stakeholders by telephone and then sent further information on the research subject and the interview by email. The interviews were conducted face-to-face at each stakeholder's desired location and were performed by the same researcher/interview partner. The first questions were about the respondent's profession and their individual and professional relation to the topic under investigation. Then, we asked the respondents to fill in a table based on their opinion on their prioritized ES and to provide the rationale to explain their selection (see Table A1.1). The interviews took place in February and March 2019 and lasted between $40 \mathrm{~min}$ and two hours (average of $45 \mathrm{~min}$ ). There were no strict time constraints to give the interviewees time for additional issues and comments that might arise. We recorded the conversations with a digital recorder and then transcribed them before carrying out the data analysis.

These were the central questions of the guideline, on which we based our analysis (see Table A1.1 for more details):

\section{Question 1: Prioritizing ecosystem services}

Which ES are considered to have the highest priority in the Black Forest region, and why? Please choose among the list of $18 \mathrm{ES}$ belonging to four categories (provisioning, cultural, regulating, and supporting ES) according to the classification of the Millennium Ecosystem Assessment (2005), the ES with your highest priority in each of the four categories, and provide the underlying reason for the selection (see question $\mathrm{a}$ and $\mathrm{b}$ in Table A1.1):

Provisioning ES: timber yield, biomass productivity, profitability, hunting potential, and non-wood forest products (NWFP)

Cultural ES: recreation activities and spiritual experience, tourism, education, collecting mushrooms, fruits, wild garlic, and other forest non-wood products, and observing plants and animals

Regulating ES: water retention, carbon storage, air pollution control, and soil and erosion protection

Supporting ES: biodiversity, tolerance to drought, resistance to storms, and protection against diseases and tree pests.

Question 2: Comparison between monospecific and mixed forests

In your perception, which type of forest (beech, fir, or mixed beech-fir forest) is more effective at providing the ES you prioritized in question 1? What reasons support your view? (See question $\mathrm{c}$ in Table A1.1)

\section{Data analysis}

The transcription of the audio files was carried out by professional service providers and verified by the authors. The transcribed interviews were evaluated using qualitative content analysis with MAXQDA 2018 Software (VERBI Software 2017), according to the guidelines by Mayring (2000). To group and categorize the information and the perceptions provided by the interviewees, we deductively developed a coding system based on theoretical background and the interview guideline. Then, we analyzed the interviews one by one and created new codes in an inductive way (from within the interview data), complementing the coding system (Glaser and Strauss 1967, Strauss 1987, Mayring 2016). The coding structure was based mainly on the table of the interview guideline on ES priorities and forest type selection. We discussed the coding structure within the research group to ensure a non-biased interpretation. Even though the study focuses on qualitative content analysis, we performed quantitative descriptive data analysis in MAXQDA to identify ES prioritized by stakeholders. The qualitative data analysis was based on these results. We applied different tools in MAXQDA (VERBI Software 2017) to analyze and summarize the data and used the tool CodeMatrixBrowser to visualize the most important arguments for the prioritization of single ES. (VERBI Software 2017).

\section{RESULTS}

Our qualitative analysis focused on the four ES prioritized by the highest number of stakeholders, one from each category. To maintain the anonymity of the stakeholders, we display their views by using a code system referring to the individual stakeholder in that group (see Table 1). For example, a stakeholder from the "state forest officers" group is referred to as F1, F2, or F3. We anonymized and earmarked the statements and quotes presented with an abbreviation in brackets indicating which stakeholder is responsible for or supported a specific statement.

\section{Reasons for prioritizing specific ES}

The four ES out of $18 \mathrm{ES}$ in total named most frequently in the respective categories are timber yield $(65 \%)$, recreational activities and spiritual experience $(75 \%)$, water retention and storage $(35 \%)$, and biodiversity $(80 \%)$. A quantitative overview of how many and which stakeholders prioritized specific ES is provided in Table 2.

The most homogeneous responses were found in the supporting ES category, where biodiversity was prioritized by 16 of the 20 stakeholders, and the reasons given by the stakeholders for this prioritization were very similar. Although there is a clear prioritization of timber yield, recreation, and biodiversity among most of the stakeholders compared to the other ES in the respecting categories, this was not the case for the regulating ES, where there were more heterogeneous responses. In the following, the most important reasons for prioritizing the four named ES will be presented. An overview of the key underlying reasons for prioritizing the four ES is provided in Table 3, which was developed using the tool Code Matrix Browser (VERBI Software 2017). Table 3 provides information about the number of stakeholders that expressed single reasons for selecting the prioritized ES. In addition, it provides a visualization of the coding system.

\section{Timber yield}

Timber is a regionally produced product and a prominent regional source of income for many forest owners and forestry businesses in the Black Forest (P1, P4, F2, R2, B1, B2, T2). Furthermore, many jobs are generated in the timber production sector, predominantly in rural regions (R4). The Black Forest is a region with a high share of managed forests. Thus profitability is an 
Table 2. Frequency of responses on prioritized ES in each category. The ecosystem services named most frequently as priority are in bold.

\begin{tabular}{|c|c|c|c|}
\hline \multicolumn{4}{|c|}{ Provisioning ecosystem services } \\
\hline & Frequency & $(\%)$ & Stakeholders \\
\hline Timber yield & 13 & 65 & B2, F1, F2, F3, N4, P1, P2, P3, P4, R1, R2, R4, T2 \\
\hline Profitability & 4 & 20 & $\mathrm{~B} 1, \mathrm{~B} 3, \mathrm{~N} 2, \mathrm{~N} 3$ \\
\hline Biomass productivity & 3 & 15 & $\mathrm{R} 3, \mathrm{~N} 1, \mathrm{~T} 1$ \\
\hline Hunting potential & 0 & 0 & \\
\hline Non-wood forest products & 0 & 0 & \\
\hline Total & 20 & 100 & \\
\hline \multicolumn{4}{|l|}{ Cultural ecosystem services } \\
\hline & Frequency & $(\%)$ & \\
\hline Recreation & 15 & 75 & B2, F1, F2, F3, N1, N3, P1, P2, P3, P4, R1, R3, R4, T1, T2 \\
\hline Tourism & 1 & 5 & $\mathrm{R} 2$ \\
\hline Education & 1 & 5 & $\mathrm{~N} 4$ \\
\hline Collecting mushrooms & 1 & 5 & B1 \\
\hline Observing plants, animals & 1 & 5 & N2 \\
\hline Not important & 1 & 5 & B3 \\
\hline Total & 20 & 100 & \\
\hline \multicolumn{4}{|l|}{ Regulating ecosystem services } \\
\hline & Frequency & $(\%)$ & \\
\hline Water retention & 7 & 35 & $\mathrm{~B} 2, \mathrm{~F} 3, \mathrm{~N} 2, \mathrm{~N} 3, \mathrm{~N} 4, \mathrm{R} 2, \mathrm{~T} 1$ \\
\hline Carbon storage & 6 & 30 & $\mathrm{~F} 2, \mathrm{~N} 1, \mathrm{P} 1, \mathrm{P} 2, \mathrm{P} 3, \mathrm{R} 4$ \\
\hline Pollution control & 4 & 20 & B3, R1, R3, T2 \\
\hline Erosion protection & 3 & 15 & $\mathrm{~B} 1, \mathrm{~F} 1, \mathrm{P} 4$ \\
\hline Air pollution control & 0 & 0 & \\
\hline Soil protection & 0 & 0 & \\
\hline Total & 20 & 100 & \\
\hline \multicolumn{4}{|l|}{ Supporting ecosystem services } \\
\hline & Frequency & $(\%)$ & \\
\hline Biodiversity & 16 & 80 & $\begin{array}{l}\text { B1, B2, F2, F3, N1, N2, N3, P1, P2, P3, P4, R1, R2, R3, T1, } \\
\text { 22 }\end{array}$ \\
\hline Tolerance to droughts & 2 & 10 & ( \\
\hline Resistance to storms & 2 & 10 & $\mathrm{~N} 4, \mathrm{R} 4$ \\
\hline Protection against diseases & 0 & 0 & \\
\hline Total & 20 & 100 & \\
\hline
\end{tabular}

important goal of forest management and depends on the revenue from timber (T1, F2, F3). Moreover, timber is a regionally produced renewable building material, which serves various purposes (P2, N2, R3, R4). As stated by F1: "it is more sustainable, if locally grown, harvested and processed instead of bringing timber here from somewhere else" (F1). Besides, timber can contribute to climate protection, as trees can sequestrate carbon dioxide and convert it into biomass. This sequestrated carbon dioxide remains for a long time as biomass, as long as the wood is not burned or used to create energy (P2, R4). Two interviewees (F3, R4) also pointed out the interconnection of timber with other ES, stating that the revenue from timber can be invested in enhancing other ecosystem services, such as tourism, recreation, and education. Therefore, as concluded by one of the researchers interviewed, "a forest that profits from the production of timber, has greater ecosystem services” (R4).

\section{Recreational activities and spiritual experience}

Three-quarters of the stakeholders selected recreational activities and spiritual experience as the most relevant cultural ecosystem service. The underlying reasons were embedded in the high cultural significance of forests and the recognized individual benefits of spending time in the woods. Forests have high cultural importance in Germany because "a German takes great pleasure in being in a forest" (P4). People enjoy recreational and leisure activities in the forest such as hiking, jogging, cycling, walking their dog, riding, and more recent additions such as mountain biking (P1, P4, T1, R1, R4, F3). For many people, a forest is a place where they can retreat to find peace and to relax. In addition to the spiritual aspect, they can experience direct contact with nature (R4).

An example of this is the current trend of "bathing in the woods" (Waldbaden). Especially, people who live in densely populated areas and spend a lot of time in an office or a car look for a place to relax, experience spirituality, and find distractions from everyday life. A forest is an optimal location for this and is considered a source for personal relaxation and individual growth (F1, P2, P3, F1, F2, F3, N3, T2, R1, and R4). As said by one of the forest policy makers: "In a forest, you can turn off and sink into your thoughts. I still always experience the greatest relaxation in the woods" (P3). Besides its cultural significance, some respondents also highlighted the positive impact on health via visual experiences, the scents, and the peace perceived when being in the forest $(\mathrm{R} 4, \mathrm{~B} 2)$. As stated by one of the respondents: "A walk in the woods is like a therapy" (B2).

Some interviewees encountered difficulties prioritizing a cultural ES because they perceived that the ES in this category are strongly 
Table 3. Frequencies of the underlying reasons for prioritizing the ES timber yield, water retention, biodiversity, and recreation. Developed with the tool CodeMatrixBrowser in MAXQDA and based on the code system developed in the same software (Verbi Software 2017).

\begin{tabular}{|c|c|c|c|c|c|c|c|c|c|c|c|c|c|c|c|c|c|c|c|c|c|}
\hline Reasons for prioritizing ES in each ES category & $\mathrm{P} 1$ & $\mathrm{P} 2$ & $\mathrm{P} 3$ & $\mathrm{P} 4$ & $\mathrm{~F} 1$ & $\mathrm{~F} 2$ & $\mathrm{~F} 3$ & $\mathrm{~B} 1$ & $\mathrm{~B} 2$ & B3 & N1 & $\mathrm{N} 2$ & N3 & N4 & $\mathrm{T} 1$ & $\mathrm{~T} 2$ & $\mathrm{R} 1$ & $\mathrm{R} 2$ & $\mathrm{R} 3$ & $\mathrm{R} 4$ & Total \\
\hline \multicolumn{22}{|l|}{ Timber yield (provisioning ES) } \\
\hline profitability also depends on timber yield & & & & & & 1 & & & & & & & & & & & & & & & 1 \\
\hline generation of jobs in the region & & & & & & & & & & & & & & & & & & & & 1 & 1 \\
\hline $\begin{array}{l}\text { many private forest owners depend on timber } \\
\text { income }\end{array}$ & & & & & & & & & 1 & & & & & & & & & & & & 1 \\
\hline promote regional timber, no need for imports & & & & & 1 & & & & & & & & & & & & & & & & 1 \\
\hline timber income for promoting the other ES & & & & & & & 1 & & & & & & & & & & & & & & 1 \\
\hline $\begin{array}{l}\text { timber stores carbon - positive for climate change } \\
\text { mitigation }\end{array}$ & & 1 & & & & & & & & & & & & & & & & & & 1 & 2 \\
\hline timber is a renewable resource & & 1 & & & & & & & & & & & & 1 & & & & & & 1 & 3 \\
\hline $\begin{array}{l}\text { our main income source, our forests are } \\
\text { production forests }\end{array}$ & 1 & & 1 & & & 1 & & & 1 & & & & & & 1 & 1 & & 1 & & 1 & 8 \\
\hline \multicolumn{22}{|l|}{ Recreation (cultural ES) } \\
\hline $\begin{array}{l}\text { observing plants, animals, collecting fruits are } \\
\text { part of recreation }\end{array}$ & & & & & & & & & & & & & & & & & 1 & & & & 1 \\
\hline positive influence on human health & & & & & & & & & & & & & & & & & & & & 1 & 1 \\
\hline relaxation and peace & & & 1 & & 1 & & & & & & & & 1 & & & & & & & & 3 \\
\hline spiritual and nature experience & & 1 & & & & & & & 1 & & & & & & & 1 & & & & 1 & 4 \\
\hline $\begin{array}{l}\text { forests as an ideal place for recreational activities } \\
\text { for tourists and locals }\end{array}$ & 1 & & & 1 & & 1 & 1 & & & & 1 & & 1 & & 1 & & 1 & & 1 & 1 & 10 \\
\hline \multicolumn{22}{|l|}{ Water retention (regulating ES) } \\
\hline water will become a scarce resource & & & & & & & & & & & & & & & & & & 1 & & & 1 \\
\hline positive impact in nearby non-forested areas & & & & & & & 1 & & & & & & & & & & & & & & 1 \\
\hline It depends on soil type & & & & & & & & & & & & 1 & & & & & & & & & 1 \\
\hline to cope with increasing droughts/climate change & & & & & & & & & & & & 1 & 1 & 1 & & & & & & & 3 \\
\hline forests as a drinking water source & & & & & & & 1 & & 1 & & & 1 & & & & & & & & & 3 \\
\hline protection against floods & & & & & & & 1 & & & & & & & & & & & & & & 1 \\
\hline \multicolumn{22}{|l|}{ Biodiversity (supporting ES) } \\
\hline productivity and biodiversity are interdependent & & & & & & & & & & & & & & & 1 & & & & & & 1 \\
\hline biodiversity research & & & & & & & & & & & & & & & & & & & 1 & & 1 \\
\hline capercaillie, a symbol for the region & & & & & & & & & & & & & & & & & & 1 & & & 1 \\
\hline ensures our existence and future & & & & & & & & & & & & & & & & & 1 & & & & 1 \\
\hline the basis for healthy forests & & & & & & & & & & & & & & & 1 & & & & & & 1 \\
\hline $\begin{array}{l}\text { positive, if it is native to a location, close to } \\
\text { nature }\end{array}$ & & & & & & & & & & & & 1 & & & & & & & & & 1 \\
\hline $\begin{array}{l}\text { the more biodiversity, the more valuable is a } \\
\text { forest }\end{array}$ & & & & & & & & & 1 & & & & & & & & & & & & 1 \\
\hline $\begin{array}{l}\text { protection of all forms of life, all biodiversity } \\
\text { levels }\end{array}$ & & & & & 1 & & 1 & & & & 1 & & & & & & 1 & & & & 4 \\
\hline $\begin{array}{l}\text { the basis for stability, resilience, adaptation to } \\
\text { extreme events }\end{array}$ & 1 & & 1 & & & & & & & & & & & & & & & & & & 2 \\
\hline
\end{tabular}

interlinked. For example, collecting mushrooms and observing plants and animals were considered recreational activities that should be part of "recreation and spiritual experience." As stated by $\mathrm{R} 1$, "In principle the other areas are partial aspects, for example collecting mushrooms, fruit, wild garlic, forest honey, and other non-wood products, there are people who collect them. But I would include that as part of recreational and leisure activities." This suggests an overlap between the cultural and the recreational values of ES and overlap between cultural and recreational ES categories, which differs from the traditional ES classification.
Water retention and carbon storage

Regarding regulating ES, there was no clear trend for prioritizing a specific ES, comparing to the other ES categories, where choices were more homogenous. Moreover, the interviewees showed particular difficulty in choosing between the ES in this category. A third $(35 \%)$ of the stakeholders named water retention as the essential regulatory ecosystem service, followed by carbon storage, which $30 \%$ of the interviewees prioritized. This result indicates that interviewees might have faced difficulties prioritizing single regulating ES, as all of them were perceived as important. The reasons for choosing both water retention and carbon storage were mainly aligned with and based on the 
awareness of climate change impacts. Indeed, three out of seven stakeholders who prioritized water retention and all stakeholders who prioritized carbon storage mentioned climate change as the underlying reasons. As stated by one of the researchers R4, "if I have to decide, very clearly, first of all the carbon storage capacity, especially in recent years under the influence of climate change" (R4). In addition, one of the policy makers (P3) emphasized that "wood as a $\mathrm{CO}_{2}$ store is becoming more and more important, because we probably won't be able to reduce the $\mathrm{CO}_{2}$ emissions to such an extent that the two-degree target will still work."

Regarding water storage, increasing drought events and possible water scarcity, as consequences of climate change, were the most important reasons for prioritizing this ES. Ongoing drought as in the years 2018 and 2019 and the resulting infestation by bark beetles have already damaged the forests. Consequently, water will increasingly be subject to temporal and spatial shortages, now and in the future (N2, N3). As stated by one of the policy makers, "Dry periods are becoming stronger and more intensive, even in the higher locations of the Black Forest" (P4). In addition, one of the researchers pointed out that, "Consequently, water is increasingly becoming a scarce resource" (R2). The retention of water is a valuable ecosystem service provided by forests, ensuring the availability of drinking water. Furthermore, the Black Forest is known for its springs of high-quality drinking water exported and sold in other regions of Germany and beyond. These springs will be endangered in the long term if drinking water becomes scarce (P3, N1, N4). A stakeholder belonging to the private owners' group (B1) also mentioned the positive effect of water retention on flood prevention.

\section{Biodiversity}

There was a high homogeneity among the choices for prioritizing specific supporting ecosystem services and the reasons provided by the stakeholders. According to $80 \%$ of the stakeholders, biodiversity is the most important supporting ES. For some interviewees, the reasons for choosing biodiversity were selfexplanatory and, thus, unnecessary for them to explain further (N4, P2, F3, T1, T2). One of the reasons for stating this is the belief that the maintenance of biodiversity is essential for the health of forests (T1) and is a priority task of forest management (R3). In addition, it is also considered a primary social task now and in the future, which is one aspect of providing public services because "people's health depends on biodiversity" (R1). However, it was pointed out that it is crucial for "the biodiversity to be sitespecific and close to nature" (P1, P3, N4). In this regard, a county forest officer pointed out that it is necessary "to protect all forms of biodiversity" (F1). In addition, a stakeholder from the tourism sector perceived a strong link between forest management and biodiversity, suggesting that "biodiversity and management belong together because only healthy forests can be managed" (T1).

Stakeholders' reasons for selecting mixed or monospecific forests There was a clear preference for mixed forests regarding the provision of ES across all categories, shown in Table 4. However, the choices in favor of a specific forest type regarding provisioning ES were rather heterogeneous because some stakeholders preferred fir forests for the provision of timber yield, profitability, and biomass productivity. Fir forests were also favored by one interviewee (B1) as superior for collecting mushrooms. Similarly, beech forests were only preferred by one stakeholder (N2) for retaining water, and another interviewee (N1) considered that mixed and beech forests have equal potential for recreation. To evaluate the reasons behind stakeholders' selections, we focus on the four ES prioritized by most of the stakeholders in each ES category: timber yield, water retention, recreation, and biodiversity.

\section{Timber yield}

The responses to the question as to which type of forest provides the greatest yield of timber were not uniform. Whereas $70 \%$ of the stakeholders stated that mixed forests were more suitable than monospecific stands for the provision of timber yield, $30 \%$ viewed monospecific forests of fir trees as preferable (B2, R1, R2, T2). The interviewees who chose fir forests belonged to different stakeholder groups: private forest owners, researchers, and tourism. The arguments below include the perceptions of stakeholders who chose mixed forests and their comments on monospecific forests.

The reasons underlying the preference for fir forests regarding timber yield were based on forest growth assumptions. For instance, various interviewees belonging to different stakeholder groups stated that monospecific fir stands have higher average growth and a higher standing volume than mixed forests $(\mathrm{P} 1, \mathrm{~N} 3$, B1, B2, R1, R2, R3). Moreover, B1 and R1 stated that the share of logs is more significant in monospecific stands of fir trees than in mixed forests because fir has a significantly smaller amount of low-quality crown wood than beech trees. Furthermore, regarding market demand, two interviewees pointed out that both the need and the value for fir wood are much higher than for beech wood, which is often sold as firewood (B1, B3). These statements were also acknowledged by the stakeholders that preferred mixed forests.

Most of the stakeholders see mixed forests as more profitable ( $\mathrm{P} 1$, $\mathrm{P} 2, \mathrm{P} 4, \mathrm{R} 4, \mathrm{~F} 1, \mathrm{~F} 2, \mathrm{~F} 3$ ), particularly in a long-term view, because having two or more species of trees enables a wider range of use of the timber and makes it possible to react to shifts in the market and to changing demand patterns (N2, F1). As stated by a forest district manager, "count me in immediately for forests of fir trees, but mixed forests are better long term" (F2). Not only are mixed forests more profitable in the view of various stakeholders, but in their opinion, mixed forests also exhibit higher stability and pose a reduced risk in extreme events compared to monospecific stands of fir. Furthermore, the timber quality can be at least as high or even higher than that in a monospecific stand (R4). As stated by two stakeholders representing forest city administrations, beech wood can also be produced in top quality. Furthermore, two stakeholders believe that a greater tree species diversity positively impacts timber yield (P4, P2). Consequently, beech-fir mixed forests can achieve an even higher yield than monospecific forests (P1).

A crucial aspect when talking about profitability and timber yield in mixed forests, as regarded by two of the interviewees, is the percentage of the mixture (P1, F3). There were different opinions on the optimal proportion of fir and beech for achieving a high timber yield. They ranged between $60 \%$ to $70 \%$ for the proportion of fir and $30 \%$ to $40 \%$ for beech. One of the researchers stated that forests with smaller shares of beech are a better option in the long term than monospecific stands of fir trees (R4). 
Table 4. Frequency of responses on the preferred forest type for the provision of the prioritized ecosystem services (ES).

\begin{tabular}{|c|c|c|c|c|c|c|c|c|}
\hline \multirow{3}{*}{$\begin{array}{l}\text { Ecosystem services } \\
\text { Provisioning ES }\end{array}$} & \multicolumn{8}{|c|}{ Selected forest type } \\
\hline & \multicolumn{2}{|r|}{$\begin{array}{l}\text { Mixed } \\
\text { forests }\end{array}$} & \multicolumn{2}{|c|}{$\begin{array}{l}\text { Fir } \\
\text { forests }\end{array}$} & \multicolumn{2}{|c|}{$\begin{array}{l}\text { Beech } \\
\text { forests }\end{array}$} & \multirow[t]{2}{*}{$\begin{array}{l}\text { Don't } \\
\text { know }\end{array}$} & \multirow[b]{2}{*}{ Total } \\
\hline & Freq. & $\mathrm{S}$ & Freq. & $\mathrm{S}$ & Freq. & $\mathrm{S}$ & & \\
\hline Timber yield & 9 & F1, F2, F3, N4, P1, P2, P3, P4, R4 & 4 & $\begin{array}{l}\text { B2, R1, R2, } \\
\text { T2 }\end{array}$ & & & & 13 \\
\hline Biomass productivity & 2 & $\mathrm{~N} 1, \mathrm{~T} 1$ & 1 & R3 & & & & 3 \\
\hline Profitability & 2 & $\mathrm{~B} 1, \mathrm{~N} 2$ & 2 & B3, N3 & & & & 4 \\
\hline Total & 13 & & 7 & & & & & 20 \\
\hline \multicolumn{9}{|l|}{ Cultural ES } \\
\hline Recreation & 14 & $\begin{array}{l}\text { B2, F1, F2, F3, N3, P1, P2, P3, P4, } \\
\text { R1, R3, R4, T1, T2 (+N1) }\end{array}$ & & & 1 & N1 & & 15 \\
\hline Collecting mushrooms & & & 1 & B1 & & & & 1 \\
\hline Education & 1 & N4 & & & & & & 1 \\
\hline Not important & 1 & B3 & & & & & & 1 \\
\hline Observing plants, animals & 1 & N2 & & & & & & 1 \\
\hline Tourism & 1 & $\mathrm{R} 2$ & & & & & & 1 \\
\hline Total & 18 & & 1 & & 1 & & & 20 \\
\hline \multicolumn{9}{|l|}{ Regulating ES } \\
\hline Water retention & 6 & $\mathrm{~B} 2, \mathrm{~F} 3, \mathrm{~N} 3, \mathrm{~N} 4, \mathrm{R} 2, \mathrm{~T} 1$ & & & 1 & N2 & & 7 \\
\hline Carbon storage & 5 & $\mathrm{~N} 1, \mathrm{P} 1, \mathrm{P} 2, \mathrm{P} 3, \mathrm{R} 4$ & 1 & $\mathrm{~F} 2$ & & & & 6 \\
\hline Erosion protection & 2 & $\mathrm{~B} 1, \mathrm{P} 4$ & & & & & $1(\mathrm{~F} 1)$ & 3 \\
\hline Pollution control & 2 & $\mathrm{R} 1, \mathrm{~T} 2$ & 2 & B3, R3 & & & & 4 \\
\hline Total & 15 & & 3 & & 1 & & 1 & 20 \\
\hline \multicolumn{9}{|l|}{ Supporting ES } \\
\hline Biodiversity & 16 & $\begin{array}{l}\text { B1, B2, F2, F3, N1, N2, N3, P1, } \\
\text { P2, P3, P4, R1, R2, R3, T1, T2 }\end{array}$ & & & & & & 16 \\
\hline Tolerance to drought & 2 & $\mathrm{~B} 3, \mathrm{~F} 1$ & & & & & & 2 \\
\hline Resistance to storms & 1 & R4 & 1 & $\mathrm{~N} 4$ & & & & 2 \\
\hline Total & 19 & & 1 & & & & & 20 \\
\hline
\end{tabular}

\section{Recreation}

The majority of the interviewees (14 of the 15) who prioritized recreation among the cultural ES, considered mixed forests better suited for those seeking relaxation and spiritual experiences than monospecific stands. These kinds of forests are considered aesthetically more attractive than monospecific stands in the view of six interviewees because they exhibit various colors (dark fir, lighter beech, leaf coloration; P1, F3, B3, R2, R3, R4). In addition, they exhibit more seasonal differences (change of color in autumn, leaves that fall or not), which lead to compelling images of the forest in every season. As expressed by two interviewees, "in the summer everything is green, and in the winter the fir trees attract your view. In comparison, beech forests look barren, sad, and boring in the winter" (B2, R4). Another reason for preferring mixed forests for recreation is the perceived higher diversity in terms of structure, height expansion, depth, and lighting (F1, T1). This is of great value in the context of relaxation and tourism because "sensory perception is expanded in mixed forests" $(\mathrm{P} 2)$.

In general, compositional and structural heterogeneity seems to be an important underlying reason for preferring mixed forests as recreation sites. This is visible in the statements of 12 stakeholders, who perceive monospecific fir forests as monotonous and therefore less preferable for recreation. They stated that forests composed of only fir trees do not change very much in the year and are perceived as boring, gloomy, dull, and dark (P1, P2, F1, F2, F3, B1, B2, T1, R1, R2, R3, and R4). However, one of the researchers working in the social aspect of forest management pointed out that not all kinds of mixtures are considered "beautiful" by forest visitors. Too much heterogeneity can also be perceived as unfavorable. According to surveys of forest visitors, he concluded that a moderate mixture of tree species is attractive for people seeking relaxation. He stated that, "People feel that images of woods that are changing without being chaotic are beautiful, variable, and moderately colorful" (R2).

One interviewee from a nature protection agency (NPA) classified mixed forests and beech forests as equal in terms of recreation potential as natural beech forests are always monospecific and they can appear very attractive because of the different ages of the trees. They emphasized that "beech forests look wonderful when they are old and have impressive trees with their crowns and scaly bark" (N3). 


\section{Water retention}

Of the seven interviewees who prioritized water retention among the regulatory services, six named beech-fir mixed forests as the type of forest that provides this service the best. One interviewee (N2), in contrast, believes that a monospecific beech forest represents the best water reservoir. He pointed out that the interception loss is higher in coniferous compared to broadleaf trees. When talking about water retention and storage, the interception capacity of water plays an essential role. Not many respondents were able to provide a reason for preferring mixed forests to provide this ES. According to four of the stakeholders, beech forests have a greater water storage capacity because, in a year, they produce less evaporation and more rainwater seeps into the ground (P3, P2, N1, R1). However, in the long term, they consider that mixed forests are a more sustainable forest type because mixed forests have a greater diversity of tree species and are more stable and less vulnerable to disturbances than beech or fir monospecific forests (P3, P4, F3). As stated by F3, "At the moment, I am shaped by the fact that a lot of fir trees are dying off. And so, I'm glad that I still have beeches. And vice versa, it could also be that the beech trees suddenly die, and then I would be happy to have fir trees. So, mixed forests are simply more stable and less vulnerable." According to a researcher and a stakeholder representing an NPA, spruce and fir monospecific stands are subjected to more significant interception loss (greater water evaporation from the leaf surface) over a year, compared to beech forests (N4, R1). This represents a problem, particularly in winter, because of less precipitation. Therefore, a larger share of mixed forests (beech-fir) would positively affect the capacity for water retention and storage of the region $(\mathrm{B} 2, \mathrm{~N} 1, \mathrm{R} 2)$.

Another critical factor influencing the water capacity of forests, as mentioned by three interviewees, is the root system of a tree. In beech-fir mixed forests, the different root systems make the ground more accessible, as the roots that die off form channels, where it is easier for water to run off. This has a positive effect on water retention and storage (R3, R4). However, as pointed out by one of the interviewees, the significance of this process depends decisively on the type of soil (N4).

\section{Biodiversity}

There was a consensus that beech-fir mixed forests are much better suited to achieve high biodiversity than monospecific forests. Three interviewees stated that the variety of tree species and the usually higher structural diversity of mixed forests lead to diverse ecological niches (B1, N1, N3), resulting in a more significant number of symbiotic communities in a smaller area (N3). Consequently, the more diverse a forest regarding tree species, the higher its biodiversity is (B2, N4). In addition, some interviewees (P1 and P3) manifested that biodiversity is the foundation of stability and equilibrium in a forest (resilience). Consequently, "a forest that is rich in biodiversity has a better balance" $(\mathrm{P} 1)$ because "species-rich ecosystems are more flexible and elastic in their reactions" $(\mathrm{P} 3)$.

\section{General perceptions on mixed forests}

In addition to the positive responses about beech-fir mixed forests, there were also warnings not to consider mixed forests to be a panacea for all the problems and challenges afflicting forests. One stakeholder in particular (B1) was skeptical, seeing neither general ecosystem advantages in mixed forests nor a clear connection to resilience to climate change. The criticism of mixed forests was concentrated on three major points: (1) mixed forests are not per se more sustainable than monospecific ones; (2) not all mixtures of different species of trees have a positive impact on ecosystem services, which are the result of multicriteria effects and normative evaluation. Advantages are expected, especially when the "right" combination of species of trees is selected, and the mixture is adapted to the location. (3) Not all monospecific forests are harmful as a matter of principle (N2, T1, R1). Close-to nature monospecific forests, such as beech forests, which naturally tend to form monospecific stands, can exhibit favorable properties similar to those of beech-fir mixed forests (N1).

The changes resulting from climate change can be met by replacing a particular tree species with another more suitable one (F3). A prominent example of a shift in tree species is the planting of fir in place of spruce. The latter exhibit low resilience, and for that reason, the share of spruce stands should be reduced wherever possible (B1, N3, P2, T1). Therefore, a stakeholder from an NPA suggested, "reducing the spruce share and increasing the fir share, because monospecific spruce forests are considered to be not suitable in the context of climate change" (N2). However, one of the researchers stated that "there is no need to actively reduce spruce in mixed stands, as this will happen naturally because of bark beetle, storms and other disturbances" (R4).

\section{DISCUSSION}

\section{Understanding the prioritized ES}

Analyzing ES priorities among stakeholders is crucial to identify and indicate critical areas of societal agreement or dissent, both within and across stakeholder groups (Hicks et al. 2013). Based on these results, decision-making processes in politics and administration can draw valuable conclusions on societally feasible pathways for forest conversion in the Black Forest region within the uncertainties of climate change impacts.

Various factors influence personal priorities and choices regarding ES, such as livelihood, occupation, individual experiences, and access to resources (Hicks et al. 2013, Tauro et al. 2018). Different stakeholders, e.g., practitioners, managers, and scientists, can prioritize specific ES, and similarities in ES ranking are likely to occur within stakeholder groups, as was shown by the investigation of Hicks et al. (2013) on ES from coral reefs. However, Hicks et al. (2013) also indicate differences between and among stakeholder groups when evaluating weights assigned to the ES by the stakeholders.

We found strong synergies among and between stakeholder groups when studying the reasons for prioritizing ES. The stakeholders prioritized timber yield, recreation, water retention, and biodiversity among the provisioning, cultural, regulating, and supporting ES categories. We found homogeneous responses among stakeholder groups regarding the prioritization of provisioning, cultural, and supporting ES and more heterogeneous reactions regarding regulating ES. However, we also found strong synergies among the underlying reasons for prioritizing water retention and carbon storage among the regulating ES, primarily based on perceived climate change threats. Our results suggest that the heterogeneities that emerged were instead at the individual level and independent of the stakeholder group. 
There are only a few comparable studies available in the literature to compare our findings because most of the assessments on the perceived importance of ES are performed across services of different ES categories, instead of comparing within an ES category, as done in our study. In addition, other ES classification systems and methods are used, and sometimes only particular ES are studied. For instance, Martín-López et al. (2012) performed face-to-face questionnaires to identify the relative importance of specific services provided by different ecosystems in Spain and found that the ES most frequently perceived by people were regulating services, e.g., air purification to be most significant. Biodiversity and nature tourism were the second and third most essential services. The high importance of air purification indicated, among other factors, awareness of the increased air pollution level in Spanish cities (Martín-Lopez et al. 2012). In our study, there was no clear prioritization of single regulating ES, suggesting that all ES in that category were perceived as important. The prioritization of water retention by seven interviewees and carbon sequestration by six interviewees indicates the awareness of climate change-related challenges in the region, first, because of the expected increment of droughts and storms, and second, forests' importance as carbon sinks. According to the Forest Condition Report 2019 of Baden Württemberg by Meining et al. (2019), forests in the region have been massively weakened by the dry, hot weather of the previous two years. The extreme drought in 2018 led to the drying of the forest soil, leading to severe losses in tree vitality. Furthermore, the frequency and severity of droughts are expected to increase in Europe over the coming decades, affecting freshwater availability (IPCC 2014, EEA 2015). In this regard, forests play a crucial role in maintaining the hydrological cycle.

Most stakeholders' highly perceived importance of timber yield is related to the vital role of forestry in the regional economy. The state of Baden-Württemberg has a growing stock of 471 million cubic meters of wood as per the latest National Forest Inventory of Germany in 2011 (LUBW 2011). This makes BadenWürttemberg the state in Germany with the second (after Bavaria) highest timber reserves. The economic value of the forestry sector is gradually declining in Germany because of climate change impacts and massive damage to trees (Rosenkranz 2018, Thünen Institute 2019). However, the forest and wood sector still contribute significantly to employment and the economy in Germany. This applies particularly to Baden-Württemberg, with an annual turnover of 31 billion Euros (Clusterportal BadenWürttemberg 2020).

According to the stakeholders that prioritized recreation and spiritual experience among the cultural ES, a forest is an ideal place for recreational activities like hiking and biking and for relaxing and disengaging from the hustle-and-bustle of daily life to behold nature. Furthermore, they perceive that being in the woods has a positive effect on their health. Numerous studies have suggested positive impacts of natural ecosystems or green areas on human health and well-being (de Groot et al. 2002, de Vries et al. 2003, Van Kamp et al. 2003, Butler and Oluoch-Kosura 2006, Tzoulas et al. 2007, Lyytimäki and Pitkänen 2020). For instance, Plieninger et al. (2013) used participatory mapping to study cultural ES in Eastern Germany and showed that stakeholders relate various cultural services and multiple locallevel sites to their well-being. Among the cultural ES, mainly aesthetic values, social relations, and educational values were reported. In addition, human well-being has a solid link to the experience of natural landscapes and species diversity. Exposure to natural systems promotes inspiration, reflection, cognitive development, and spiritual enrichment (de Groot et al. 2002, Gallagher 2007).

There was unanimous agreement on prioritizing biodiversity among the supporting ES. Similarly, Martín-López et al. (2014) found high perceived importance of the satisfaction for conserving biodiversity. They assessed the importance people gave to particular ES in Spain and categorized the satisfaction for conserving biodiversityamong the cultural ES. Biodiversity is not only an important research topic in the scientific community, but it has also become one of the most relevant discussion subjects in environmental policy in the last decades (Bengtsson et al. 2000). The stakeholders' statements indicate that they see biodiversity as the fundamental basis for the health of ecosystems and humans. The scientific community confirms this statement. Rapport (1995) and Tzoulas et al. (2007), for instance, consider biodiversity to be one of the leading indicators of ecosystem health and the basis for all ecosystem processes, functions, and services on which human life depends, including primary production, carbon storage, water retention, and provision of clean water (Bengtsson et al. 2000). A general advantage of biodiversity is explained by the "insurance hypothesis," which suggests that higher levels of diversity lead to a more reliable ecosystem functioning over time under varying environmental conditions (Bengtsson et al. 2000). This hypothesis is relevant, particularly when considering climate change impacts. Even though biodiversity was prioritized among the supporting ES by most stakeholders, many of them did not provide explanations for this prioritization, claiming that the importance of biodiversity is self-explanatory. This suggests the need for further research on people's understanding of biodiversity in forest management and the use of other approaches for assessing this ES, for instance, from a cultural perspective, like that of Martín-López et al. (2014).

Our results indicate that tangible values, such as timber yield potential and intrinsic values, like nature appreciation and natureassociated well-being, influenced the priorities assigned to ES by stakeholders. This complies with the findings from Tauro et al. (2018), who studied prioritized ES by cattle ranchers in the Pacific Coast of Mexico.

Potential conflicts between nature conservation and forest productivity have been identified by Niedermann-Meier et al. (2010), particularly between a targeted quality of timber and the desire for large habitat trees. The preservation of habitat trees for promoting biodiversity is associated with losses from wood products for the forest owner. In contrast, we did not identify trade-offs in the reasons underlying prioritized ES, but rather stakeholders highlighted various synergies between ES. For example, a forester (F3) stated that timber yield revenue could be used to enhance other ecosystem services. Also, a synergy among the different recreation activities was mentioned. We found out that stakeholders perceived interconnections between cultural ES, making it challenging to prioritize single ES. According to one stakeholder, "collecting mushrooms" and "observing plants and animals" are recreation activities and should be together with "recreation and spiritual experience." This suggests the 
importance of future research studies to consider interconnections between ES and look beyond ES categories when assessing priorities. A suggestion would be to ask stakeholders, in future research, about their perceived interconnections and synergies between ES before eliciting the priorities and preferences of single ES. A comparison between different ES provided by forests across ES categories is also needed for finding potential conflicts or trade-offs between ES.

\section{Understanding underlying reasons for selecting forest types for the provision of ES}

The importance of understanding stakeholders' needs and expectations before starting a forest conversion process was highlighted by Grilli et al. (2016). They studied the link between the perceived importance of specific ES and the perceived effectiveness of their provision in mixed forests. Grilli et al. (2016) suggest that the importance of landscape values, biodiversity, and carbon sequestration might be linked to the perception that mixed forests are better at providing ES. Similarly, Carnol et al. (2014) pointed out the demand for investigating stakeholders' perceptions of ES for effective policy development. They studied the perception of stakeholders regarding the provision of ES in mixed and monospecific forests in Belgium and found positive perceptions regarding cultural, supporting, and regulating ES, while provisioning ES were perceived as equal in mixed and monospecific species stands. A positive attitude toward mixed forests was also confirmed by our previous study on stakeholder's perceptions of ecosystem services provided by mixed and monospecific forests of fir and beech (Almeida et al. 2018). However, provisioning ES were perceived as being equally or even better provided in monospecific forests.

Our results comply with Carnol et al. (2014) with regard to the perceived superior provision of recreation (cultural ES), water retention (regulating ES), and biodiversity (supporting ES) in mixed forests. Conversely to Carnol et al. (2014) and to our previous study (Almeida et al. 2018), we found that most of the stakeholders also perceived a superior provision of timber yield in mixed forests. However, divergent perceptions and arguments underlying forest type preferences emerged at the individual level regarding timber yield (provisioning ES).

A positive relationship between provisioning ES and mixed forests has been reported in experimental forest studies. As an example, Schwarz and Bauhus (2019) studied the influence of mixing beech and fir on tree growth and found positive effects on both species when growing in mixed neighborhoods. Moreover, positive effects of species richness, functional and structural diversity in forest productivity were recorded in boreal, temperate, and Mediterranean forests (Vilà et al. 2007, Morin et al. 2011, Paquette and Messier 2011, Gamfeldt et al. 2013, Pretzsch 2013, Dănescu et al. 2016).

One of the main reasons for preferring fir forests for the provision of timber yield, as mentioned by some of the stakeholders (see Table 5), was that better timber quality can be reached in pure fir stands compared to mixed stands. In addition, there is a higher market demand for fir timber. However, most of the stakeholders see mixed forests as a more sustainable option in the long-term perspective. The perception of higher flexibility to market demands and the awareness of climate change impacts, such as increasing drought and storm events, representing a considerable risk for forest management, were some of the key reasons to prefer mixed forests. Petráš et al. (2016) studied timber quality in mixed fir-spruce-beech stands and provided a more differentiated picture on this issue. Those researchers concluded that fir and spruce's timber quality was slightly lower in mixed than pure stands, while beech timber quality was considerably lower in mixed stands.

Nevertheless, they encourage mixed forests, particularly when considering their higher resistance to climate change. Pretzsch et al. (2014) also conclude that mixed forests, because of their greater biodiversity and stability, are considered to provide better response strategies to extreme events like storms and increasing droughts. Moreover, Huth and Wagner 2013, who studied ecosystem services of continuous cover forests, stated that monofunctional forests show less flexibility toward unpredicted climate change impacts and market fluctuations.

When looking at technical studies, there is evidence of overyielding in biomass production in mixed forests compared to monospecific stands in boreal and temperate forests of different tree species, particularly in sites with limited resources (Morin et al. 2011, Paquette and Messier 2011, Pretzsch 2013). However, whether mixed or monospecific forests are more productive depends on a wide range of factors, including management practices, environmental gradients and climate, forests' successional stage, intra- and interspecific interaction, and complementarity effects of rooting systems (Pretzsch et al. 2014).

Regarding cultural ES, all stakeholders perceived a higher provision of recreation and spiritual experience in mixed forests of beech and fir. Their choice was strongly linked to aesthetic values, stimulation of senses, and a sense of diversity and beauty, such as a greater variety of leaf colors, different light conditions, and seasonal changes in mixed forests. Edwards et al. (2012) and Ribe (1989) also found a preference for mixed forests of conifers and deciduous trees regarding recreation and other cultural ecosystem services because they show higher aesthetical advantages (Edwards et al. 2012). The provision of cognitive stimuli in natural environments and green space was previously highlighted by Keniger et al. (2013), Tost et al. (2019), and Lyytimäki and Pitkänen (2020). The importance of attractiveness, aesthetics, or sense of beauty has been reported in several studies on preferences of natural ecosystems (Brown and Daniel 1984, Ribe 1989). According to the stakeholders' views reported in our study, higher number of tree species, structural richness, and differences in tree age are important for recreation. Similar results were found by Edwards et al. (2012), indicating that the recreational value of forests increases with the age of forests but decreases with higher management intensity of the stand. Moreover, the size of the trees is also a factor influencing the recreational value positively, with a preference for larger and older trees (Ribe 1989, Gundersen and Frivold 2008, Edwards et al. 2012, Almeida et al. 2018). However, "high-quality indicators" to assess cultural ES of forests are not yet available (Maes et al. 2012). Thus, this makes it difficult to measure and compare the benefits of recreation and spiritual experience in different forest stands, among other cultural services. The strong preference for mixed forests and its association with personal well-being could be related to personal attitudes toward other ES, even more than other socioeconomic variables, such as gender and education, as 
Table 5. Reasons for selecting mixed fir/beech stands or monospecific stands with a better provision of the prioritized ecosystem services (ES).

\begin{tabular}{ll}
\hline \hline Key Arguments & Quotations \\
\hline Mixed forest are providing timber better than monospecific fir or beech stands \\
$\begin{array}{l}\text { Long-term view important } \\
\text { Reduced risks }\end{array}$ & "Count me in immediately for forests of fir trees, but mixed forests are better long term." (F2) \\
$\begin{array}{l}\text { Quality of timber } \\
\text { Higher security }\end{array}$ & "The quality of timber is at least as high in mixed forests or even higher compared to monospecific forests." (R4) \\
$\begin{array}{l}\text { Mixture proportion } \\
\text { React better to changing market }\end{array}$ & "You have a higher security in a mixed forest, because you have alternative uses with the two tree species." (F1) \\
demands & "We need higher proportion of fir and at least 40\% of beech mixture." (P1) \\
of income you get from timber is dependent on the market. With two different tree species, I have a diversification
\end{tabular}

Monospecific fir stands are better than mixed beech/fir tree stands

Less risks at long-term view

"The yield from fir timber is higher, however mixed forests with a small proportion of beech could be a better option in the long term, as they are less prone to risks." (R1)

"Fir forests have a higher standing volume and therefore a higher timber yield." (R2)

Higher standing volume of fir trees Less crown wood of fir trees

"Fir trees have higher share of logs and not so much crown wood, as is the case in beech trees." (B1)

Higher market demand for softwood "The demand for softwood in the market is higher. Beech logs have less value in the market. We sell $90 \%$ of our beech wood as firewood." (B3)

Mixed forests provide better recreation opportunities and have higher tourism potential than monospecific forests

Higher diversity and changes "Variety and change are important factors influencing recreation and tourism. In mixed forests, there are higher variations and changes throughout seasons, leaves that fall off, higher diversity in forms, blooming ... " ( F3)

"The different effects of light are higher in mixed forests, there are different forest pictures. In turn, fir forests are

Light effects: fir forests are dark and monotonous

Heterogeneity monotonous, dark, and gloomy." (B2)

"Heterogeneity should be there; forest ecosystems that only consist of one species are perceived to be monotonous." (R1)

Feelings associated with forest images "Beech forests in winter don't have leaves; it looks boring, sad, and bare. Fir forests don't change so much throughout the seasons."

Diverse, changing forest images, but not "A moderate mixture is good for recreation, attractive forest images that are diverse, but are not chaotic. Forest chaotic images should be colorful, but peaceful." (R2)

Mixed forests have a higher water retention capacity than monospecific forests of fir or beech

More tree species

Interception losses are greater in fir

forests

Better soil formation

Different root systems

"The more tree species, the better the water storage capacity." (N1)

"The interception losses in winter are greater in fir forests, as there is a higher evaporation." "More water reaches the ground in beech forests. In conclusion, mixed forests are better." (P3)

"There is better soil formation in mixed forests. Therefore, the water storage capacity of the soil is also higher." (T1)

"In beech-fir mixed forests, the different root systems make the ground more accessible because the roots that die off form channels, where it is easier for water to run off." (R3)

Mixed forests are more stable

"At the moment I am shaped by the fact that a lot of fir trees are dying off. And so I'm glad that I still have beeches.

And vice versa, it could be that the beech trees suddenly die and then I would be happy to have fir trees. So, mixed

forests are simply more stable and less vulnerable." (F3)

Mixed forests have greater biodiversity than monospecific fir or beech forests

Greater diversity of plants and animals "A forest with two tree species, assuming these are appropriate to the habitat, leads to a wider diversity of plants and trees." (P1)

Diversity at landscape scale also important

"While at a local scale a mixed forest can provide greater diversity than a monospecific stand, the landscape scale offers a different perspective. Small-sized monospecific stands can form a diverse mosaic, and together with the patches of the mixed forest can provide greater biodiversity than large areas of mixed forests." (R1)

Better balance "A forest that is rich in biodiversity has a better balance." (P1)

Beech forests provide better or equal recreation opportunities compared to mixed forests

Nice when old

"They look nice when they are old, with their imposing tree crown, scaly bark, and black woodpecker caves." (N3)

Note: N3 chose mixed forests.

Beech and mixed forests equivalent

"Both mixed and beech forests are for me equivalent." (N1)

Beech forests are more advantageous than mix of fir forests regarding water retention

Interception loss higher in fir forests "The interception loss is higher in coniferous compared to broadleaf trees; fir has more disadvantages compared to beech." (N2)

found by Grilli et al. (2016). Moreover, Grilli et al. (2016) state that people who acknowledge the importance of non-productive ES are more likely to prefer mixed forests.

Most of the interviewees who prioritized water retention (6 out of 7) think that mixed forests have a higher water retention capacity than monospecific forests of fir and spruce. Similarly,
Pretzsch et al. (2014:1306) suggested the importance of the "dependence of species mixing-effects on water supply in view of climate change," as many drought events are expected. Armbruster et al. (2004) also recommended the establishment of mixed forests. They developed a model to evaluate potential hydrological effects of different tree species composition, mainly spruce, mixed stands, and beech-dominated stands. Also, Schwarz 
and Bauhus (2019) advocated mixtures of beech and fir as an alternative for more drought-sensitive stands like spruce monocultures.

Regarding studies on European beech, Chakraborty et al. (2017) found that among other factors, increasing soil water storage capacity and tree species diversity are related to the higher vitality of beech trees, particularly in drought-stressed forests. However, various factors need to be considered when studying the water cycle of mixed and monospecific forests. Species selection and species interaction, such as competition and facilitation, management intervention such as thinning (Sohn et al. 2016), are crucial factors influencing the use and distribution of water in beech-fir mixed forests. Moreover, phenomena of hydraulic lift, interception, and transpiration need to be better understood to assess the use and retention of water in forests (Dawson 1993, Pretzsch et al. 2014).

According to two stakeholders' responses (N4, R1), interception rates are lower in beech-fir mixed forests, positively affecting water retention as more water reaches the ground. Likewise, it has been reported by the EEA (2015) that "high amounts of water are lost from tree canopies and soil by interception and evapotranspiration" (EEA 2015:8). At the same time, these effects can be compensated by higher transpiration of beech during the growing season (Armbruster et al. 2004). However, rates of interception and transpiration of beech and fir in mixture remain poorly understood, and indicators to assess the contribution of forests to water provision are scarce (Maes et al. 2016). The hydraulic lift is a phenomenon whereby plants with deep root systems redistribute water to surface-near soil horizons, making it available to neighboring shallow rooting plants (Gallagher 2007, Pretzsch et al. 2014). Pretzsch et al. (2014) suggested that this facilitation mechanism could explain a more effective water use in mixed stands of beech and spruce. In a study on the effects of admixing firs to beech forests, an improved water supply for beech in sites with low precipitation was found (Magh et al. 2018). However, more evidence is needed to conclude on water supply as an effect of mixing fir and beech.

There was consensus among the stakeholders that mixed forests of beech and fir provide higher biodiversity than monospecific forests, mainly because they believe that more tree species provide a greater variety of habitats and niches for different types of fauna and flora (B2, N4). In addition, three stakeholders stated that a higher structural richness in mixed forests supports biodiversity (B1, N1, and N3). Several authors have suggested that speciesrich communities have higher stability, resilience, and resistance against invaders and disturbances than homogenous or speciespoor communities (Peterson et al. 1998, Bengtsson et al. 2000, Loreau et al. 2001). In addition, positive effects of diversity in productivity have been found in mixed forests compared to monocultures and mixed forests (Tzoulas et al. 2007). Therefore, as emphasized by three interviewees, it is of utmost importance to ensure biodiversity conservation (P1, P3, N4). For this purpose, species diversity and functional and genetic diversity (from forest stand to landscape-scale) need to be considered. However, Bengtsson et al. (2000) stated that splitting European forests into conservation forest areas and high-intensity managed forests will not be enough to preserve biodiversity. The promotion of sustainably managed multifunctional mixed forests would be an optimal strategy to enhance biodiversity while ensuring other ES like timber yield, recreation, and water retention.

Several stakeholders suggested focusing not only on fir and beech monospecific forests but also on monospecific spruce forests (B1, N3, P2, T1). Spruce is the most common tree species in the Black Forest region and is an essential source of timber. At the same time, it is considered the most sensitive tree species to climate change impacts, such as droughts, storms, and other calamities, like bark beetle infestation (Albrecht et al. 2019). Therefore, the interviewees suggested increasing mixed forest shares while replacing spruce with fir at appropriate sites. Similarly, Meining et al. (2019) state that a forest can become more resilient toward climate change by converting monospecific spruce forest stands into mixed forests.

\section{Conceptual contributions of the study}

The stakeholder analysis based on the power-interest grid can be an effective method for identifying relevant stakeholders interested in a specific topic and influencing its outcome. However, some stakeholders might not agree or might not be interested in participating in an interview, thus affecting the project results. Moreover, that does not mean that stakeholders with low power and low interest should not be engaged in research studies, as stakeholder's interests and power can change over time. Therefore, different strategies are needed to engage those stakeholders to know their perceptions.

We found a synergy in the perceived importance (prioritization) of forests' ecosystem services between stakeholder groups, with minor differences. Most interviewees perceive that timber production is not better provided in monospecific forests in the long term. On the contrary, mixed forests were preferred for the provision of timber because of the awareness that they are more resilient toward climate change impacts and extreme events. This result contrasts with our previous analysis on ecosystem services of mixed and monospecific forests of fir and beech (Almeida et al. 2018).

\section{Limitations of the study}

We were not able to elicit the perceptions of timber industries because of a lack of interest in participating in our interviews, which warrants the inclusion of timber industry representatives in future research. We did not include questions on stakeholders' general attitudes and values toward nature. In future research studies, this information could provide a broader perspective about the reasons for prioritizing ES of stakeholders or individuals beyond belonging to a specific stakeholder group. The stakeholders' perceptions of ES could not be compared between categories, such as regulating ES and provisioning ES, or between provisioning ES and cultural ES. A comparison between ES categories could be helpful to find out ways to reduce potential trade-offs between ES and should be included in future research in this field.

\section{CONCLUSION}

This study highlights the importance of studying the perceptions, choices, and priorities of different stakeholders regarding forest ecosystems and their ES. Among 18 ES, the 20 interviewed stakeholders prioritized timber yield, recreation and spiritual experience, water retention, and biodiversity within the provisioning, cultural, regulating, and supporting ES categories, 
respectively. The priority choices were homogeneous, except for the regulating ES, where water retention and carbon storage received almost the same number of votes. The reasons for prioritizing ES were heterogeneous at the individual level but did show a common trend at the stakeholder level.

Regarding the preference for a forest type (monospecific beech, monospecific fir, or beech-fir mixed forests) for ES provision, there was a general preference for mixed forests for the provision of the four prioritized ES. However, heterogeneous responses emerged in regards to timber yield. Timber yield, which plays an essential role in the regional economy, is considered better provided in monospecific fir stands in a short-term view. However, most interviewees viewed mixed forests as advantageous compared to monospecific stands concerning a sustainable forestbased bioeconomy because of the uncertainties of climate change and changing market preferences and conditions. According to stakeholders' views, mixed forests are considered more sustainable and, in the long term, more profitable economically because of lower risk than monospecific forests.

The preferences for mixed forests were mainly shaped by an existing awareness among stakeholders of climate change-related impacts in the region, in particular increasing droughts and storms, and in addition, by their view that mixed forests could adapt better to climate change impacts. Moreover, the personal preferences for mixed forests influenced their choices because of a stronger feeling of well-being, higher perceived diversity of species, structure, foliage colors, and aesthetic aspects. In our study, no strong heterogeneities at a stakeholder-group level were visible regarding the prioritized ES and forest choices. However, additional studies using a comparison between ES categories are recommended to identify possible heterogeneities that did not emerge in this study. In addition, further assessments on weights assigned to ES might help find potential areas of conflicts or trade-offs among and between ES.

Based on stakeholders' priorities and forest type preferences, we conjecture that there may be public support for converting monospecific to mixed forests in the region of the Black Forest. Forest transformation is a required climate change adaptation strategy to increase ES among the population because the Black Forest is gradually becoming warmer, drier, and more prone to storms and tree diseases.

Responses to this article can be read online at: https://www.ecologyandsociety.org/issues/responses. php/12723

\footnotetext{
Acknowledgments:

We would like to thank the Federal Ministry for the Environment, Nature Conservation and Nuclear Safety (BMUB) and to the Federal Ministry of Food and Agriculture (BMEL) for funding this research project (FKZ 22 WC406902).
}

\section{Data Availability:}

Datalcode sharing is not applicable to this article because no datal code were analyzed in this study.

\section{LITERATURE CITED}

Albrecht, A., M. Hans-Gerd, and U. Kohnle. 2019. Baumarteneignung 2.0 und Vulnerabilitätskarten - Konzept und landesweite Hauptergebnisse. FVA-einblick 2:9-14.

Almeida, I., C. Rösch, and S. Saha. 2018. Comparison of ecosystem services from mixed and monospecific forests in southwest Germany: a survey on public perception. Forests 9 (10):627. https://doi.org/10.3390/f9100627

Armbruster, M., J. Seegert, and K. H. Feger. 2004. Effects of changes in tree species composition on water flow dynamicsmodel applications and their limitations. Plant and Soil 264(12):13-24. https://doi.org/10.1023/b:plso.0000047716.45245.23

Bengtsson, J., S. G. Nilsson, A. Franc, and P. Menozzi. 2000. Biodiversity, disturbances, ecosystem function and management of European forests. Forest Ecology and Management 132 (1):39-50. https://doi.org/10.1016/S0378-1127(00)00378-9

Biosphärengebiet Schwarzwald. 2021. Natur- und Lebensräume: Partnerschaft zwischen Mensch und Natur. Biosphärengebiet Schwarzwald, Schönau im Schwarzwald, Germany. [online] URL: https://www.biosphaerengebiet-schwarzwald.de/natur-undlebensraeume/

Bodin, P., and B. L. B. Wiman. 2007. The usefulness of stability concepts in forest management when coping with increasing climate uncertainties. Forest Ecology and Management 242 (2-3):541-552. https://doi.org/10.1016/j.foreco.2007.01.066

Brang, P., P. Spathelf, J. B. Larsen, J. Bauhus, A. Boncčína, C. Chauvin, L. Drössler, C. García-Güemes, C. Heiri, G. Kerr, M. J. Lexer, B. Mason, F. Mohren, U. Mühlethaler, S. Nocentini, and M. Svoboda. 2014. Suitability of close-to-nature silviculture for adapting temperate European forests to climate change. Forestry 87(4):492-503. https://doi.org/10.1093/forestry/cpu018

Brown, T. C., and T. C. Daniel. 1984. Modeling forest scenic beauty: concepts and application to ponderosa pine. U.S. Forest Service, Rocky Mountain Forest and Range Experiment Station, Fort Collins, Colorado, USA. https://doi.org/10.5962/bhl. $\underline{\text { title. } 98656}$

Butler, C. D., and W. Oluoch-Kosura. 2006. Linking future ecosystem services and future human well-being. Ecology and Society 11(1):30. https://doi.org/10.5751/ES-01602-110130

Carnol, M., L. Baeten, E. Branquart, J. C. Grégoire, A. Heughebaert, B. Muys, Q. Ponette, and K. Verheyen. 2014. Ecosystem services of mixed species forest stands and monocultures: comparing practitioners' and scientists' perceptions with formal scientific knowledge. Forestry 87(5):639-653. https:// doi.org/10.1093/forestry/cpu024

Chakraborty, T., S. Saha, A. Matzarakis, and A. Reif. 2017. Influence of multiple biotic and abiotic factors on the crown dieback of European beech trees at their drought limit. Flora 229:58-70. https://doi.org/10.1016/j.flora.2017.02.012 
Clusterportal Baden-Württemberg. 2020. ClusterDaten: Forst und Holz. ClusterAgentur Baden-Württemberg, Stuttgart, Germany. [online] URL: https://www.clusterportal-bw.de/ clusterdaten/technologiefelder/technologiefelder-detailseite/forstund-holz/clusterdb/Innovationsfeld/show/

Dănescu, A., A. Albrecht, and J. Bauhus. 2016. Structural diversity promotes productivity of mixed, uneven-aged forests in southwestern Germany. Oecologia 182(2):319-333. https://doi. org/10.1007/s00442-016-3623-4

Dawson, T. E. 1993. Hydraulic lift and water use by plants: implications for water balance, performance and plant-plant interactions. Oecologia 95(4):565-574. https://doi.org/10.1007/ BF00317442

de Groot, R. S., M. A. Wilson, and R. M. J. Boumans. 2002. A typology for the classification, description and valuation of ecosystem functions, goods and services. Ecological Economics 41(3):393-408. https://doi.org/10.1016/S0921-8009(02)00089-7

de Vries, S., R. A. Verheij, P. P. Groenewegen, and P. Spreeuwenberg. 2003. Natural environments-healthy environments? An exploratory analysis of the relationship between greenspace and health. Environment and Planning A 35(10):1717-1731. https://doi.org/10.1068/a35111

Edwards, D. M., M. Jay, F. S. Jensen, B. Lucas, M. Marzano, C. Montagné, A. Peace, and G. Weiss. 2012. Public preferences across Europe for different forest stand types as sites for recreation. Ecology and Society 17(1):27. https://doi.org/10.5751/ES-04520-170127

Endler, C., and A. Matzarakis. 2011. Climate and tourism in the Black Forest during the warm season. International Journal of Biometeorology 55(2):173-186. https://doi.org/10.1007/s00484-010-0323-3

Endler, C., K. Oehler, and A. Matzarakis. 2010. Vertical gradient of climate change and climate tourism conditions in the Black Forest. International Journal of Biometeorology 54(1):45-61. https://doi.org/10.1007/s00484-009-0251-2

European Commission. 2011. EU Biodiversity Strategy to 2020. European Commission, Brussels, Belgium.

European Environmental Agency (EEA). 2015. Water-retention potential of Europe's forests. A European overview to support natural water-retention measures. EEA Technical report No. 13/2015. Publications Office of the European Union, Luxembourg.

ForstBW. [date unknown]. Wald im Land: Schwarzwald. ForstBW, Tübingen-Bebenhausen, Germany. [online] URL: https://www.forstbw.de/wald-im-land/zahlenwunder/strukturen/ wuchsgebiete/schwarzwald/

Freeman, R. E. 1984. Strategic management: a stakeholder approach. Pitman, Boston, Massachusetts, USA.

Gallagher, W. 2007. The power of place: how our surroundings shape our thoughts, emotions, and actions. Poseidon, New York, New York, USA.

Gamfeldt, L., T. Snäll, R. Bagchi, M. Jonsson, L. Gustafsson, P. Kjellander, M. C. Ruiz-Jaen, M. Fröberg, J. Stendahl, C. D. Philipson, G. Mikusiński, E. Andersson, B. Westerlund, H.
Andrén, F. Moberg, J. Moen, and J. Bengtsson. 2013. Higher levels of multiple ecosystem services are found in forests with more tree species. Nature Communications 4:1340. https://doi.org/10.1038/ ncomms 2328

Glaser, B. G., and A. L. Strauss. 1967. Discovery of grounded theory. Aldine, Chicago, Illinois, USA.

Gregow, H., A. Laaksonen, and M. E. Alper. 2017. Increasing large scale windstorm damage in Western, Central and Northern European forests, 1951-2010. Scientific Reports 7:46397. https:// doi.org/10.1038/srep46397

Grilli, G., J. Jonkisz, M. Ciolli, and J. Lesinski. 2016. Mixed forests and ecosystem services: investigating stakeholders' perceptions in a case study in the Polish Carpathians. Forest Policy and Economics 66:11-17. https://doi.org/10.1016/j.forpol.2016.02.003

Gundersen, V. S., and L. H. Frivold. 2008. Public preferences for forest structures: a review of quantitative surveys from Finland, Norway and Sweden. Urban Forestry and Urban Greening 7 (4):241-258. https://doi.org/10.1016/j.ufug.2008.05.001

Hicks, C. C., N. A. J. Graham, and J. E. Cinner. 2013. Synergies and tradeoffs in how managers, scientists, and fishers value coral reef ecosystem services. Global Environmental Change 23 (6):1444-1453. https://doi.org/10.1016/j.gloenvcha.2013.07.028

Huth, F., and S. Wagner. 2013. Ökosystemleistungen von Dauerwäldern - eine aktuelle Analyse des Waldbaus. Schweizerische Zeitschrift fur Forstwesen 164(2):27-36. https:// doi.org/10.3188/szf.2013.0027

Intergovernmental Panel on Climate Change (IPCC). 2014. Climate change 2014: synthesis report. Contribution of Working Groups I, II and III to the Fifth Assessment Report of the Intergovernmental Panel on Climate Change. Core Writing Team, R. K. Pachauri, and L. A. Meyer, editors. IPCC, Geneva, Switzerland.

Jacobs, S., N. Dendoncker, B. Martín-López, D. N. Barton, E. Gomez-Baggethun, F. Boeraeve, F. L. McGrath, K. Vierikko, D. Geneletti, K. J. Sevecke, N. Pipart, E. Primmer, P. Mederly, S. Schmidt, A. Aragão, H. Baral, R. H. Bark, T. Briceno, D. Brogna, P. Cabral, R. De Vreese, C. Liquete, H. Mueller, K. S. H. Peh, A. Phelan, A. R. Rincón, S. H. Rogers, F. Turkelboom, W. Van Reeth, B. T. van Zanten, H. K. Wam, and C. L. Washbourn. 2016. A new valuation school: integrating diverse values of nature in resource and land use decisions. Ecosystem Services 22:213-220. https:// doi.org/10.1016/j.ecoser.2016.11.007

Keniger, L. E., K. J. Gaston, K. N. Irvine, and R. A. Fuller. 2013. What are the benefits of interacting with nature? International Journal of Environmental Research and Public Health 10(3):913935. https://doi.org/10.3390/ijerph10030913

Landesanstalt für Umwelt Baden-Württemberg (LUBW). 2011. Klimawandel und Anpassung: Hintergrund und Eckdaten. LUBW, Karlsruhe, Germany. [online] URL: https://www.lubw. baden-wuerttemberg.de/klimawandel-und-anpassung/wald-hintergrundund-eckdaten

Landesanstalt für Umwelt Baden-Württemberg (LUBW). 2020a. Schutzgebietsstatistik Baden-Württemberg. LUBW, Karlsruhe, Germany. 
Landesanstalt für Umwelt Baden-Württemberg (LUBW). 2020b. Klimawandel und Anpassung: Holzproduktion. LUBW, Karlsruhe, Germany. [online] URL: https://www.lubw.badenwuerttemberg.de/klimawandel-und-anpassung/holzproduktion

Leverty, S. 2008. NGOs, the UN and APA. Office of International Affairs, American Psychological Association, Washington, D.C., USA. [online] URL: https://www.apa.org/international/unitednations/publications\#: : text=APA $\% 20$ is $\% 20 \mathrm{also} \% 20 \mathrm{a} \% 20$ member $\%$ 20of $\% 20$ the $\% 20$ Conference, to $\% 20$ the $\% 20$ principles $\% 20$ and $\%$ 20programs $\% 20$ of $\% 20$ the $\% 20$ UN

Loreau, M., S. Naeem, P. Inchausti, J. Bengtsson, J. P. Grime, A. Hector, D. U. Hooper, M. A. Huston, D. Raffaelli, B. Schid, D. Tilman, and D. A. Wardle. 2001. Biodiversity and ecosystem functioning: current knowledge and future challenges. Science 294:804-808. https://doi.org/10.1126/science.1064088

Ludemann, T. 2005. Natürliche Baumartenzusammensetzung Standortswald. Pages 96-100 in K. von Teuffel, M. Baumgarten, M. Hanewinkel, W. Konold, U. H. Sauter, H. Spiecker, and K. von Wilpert, editors. Waldumbau für eine zukunftsorientierte Waldwirtschaft. Springer Verlag, Berlin, Germany.

Lyytimäki, J., and K. Pitkänen. 2020. Perceived wellbeing effects of ecosystems in Finland. Human Ecology 48(3):335-345. https:// doi.org/10.1007/s 10745-020-00155-3

Maes, J., C. Liquete, A. Teller, M. Erhard, M. L. Paracchini, J. I. Barredo, B. Grizzetti, A. Cardoso, F. Somma, J. E. Petersen, A. Meiner, E. R. Gelabert, N. Zal, P. Kristensen, A. Bastrup-Birk, K. Biala, C. Piroddi, B. Egoh, P. Degeorges, C. Fiorina, F. SantosMartín, V. Naruševičius, J. Verboven, H. M. Pereira, J. Bengtsson, K. Gocheva, C. Marta-Pedroso, T. Snäll, C. Estreguil, J. SanMiguel-Ayanz, M. Pérez-Soba, A. Grêt-Regamey, A. I. Lillebø, D. A. Malak, S. Condé, J. Moen, B. Czúcz, E. G. Drakou, G. Zulian, and C. Lavalle. 2016. An indicator framework for assessing ecosystem services in support of the EU Biodiversity Strategy to 2020. Ecosystem Services 17:14-23. https://doi. org/10.1016/j.ecoser.2015.10.023

Maes, J., M. L. Paracchini, G. Zulian, M. B. Dunbar, and R. Alkemade. 2012. Synergies and trade-offs between ecosystem service supply, biodiversity, and habitat conservation status in Europe. Biological Conservation 155:1-12. https://doi.org/10.1016/ j.biocon.2012.06.016

Magh, R.-K., M. Grün, V. E. Knothe, T. Stubenazy, J. Tejedor, M. Dannenmann, and H. Rennenberg. 2018. Silver-fir (Abies alba MILL.) neighbors improve water relations of European beech (Fagus sylvatica L.), but do not affect $\mathrm{N}$ nutrition. Trees 32 (1):337-348. https://doi.org/10.1007/s00468-017-1557-z

Maier, C., T. Lindner, and G. Winkel. 2014. Stakeholders' perceptions of participation in forest policy: a case study from Baden-Württemberg. Land Use Policy 39:166-176. https://doi. org/10.1016/j.landusepol.2014.02.018

Martín-López, B., E. Gómez-Baggethun, M. García-Llorente, and C. Montes. 2014. Trade-Offs across value-domains in ecosystem services assessment. Ecological Indicators 37:220-228. https://doi.org/10.1016/j.ecolind.2013.03.003

Martín-López, B., I. Iniesta-Arandia, M. García-Llorente, I. Palomo, I. Casado-Arzuaga, D. G. Del Amo, E. Gómez-
Baggethun, E. Oteros-Rozas, I. Palacios-Agundez, B. Willaarts, J. A. González, F. Santos-Martín, M. Onaindia, C. LópezSantiago, and C. Montes. 2012. Uncovering ecosystem service bundles through social preferences. PLoS ONE 7(6):e38970. https://doi.org/10.1371/journal.pone.0038970

Mayring, P. 2000. Qualitative Inhaltsanalyse. Grundlagen und Techniken. 7. Auflage. Deutscher Studien Verlag, Weinheim, Germany.

Mayring, P. 2016. Qualitative Inhaltsanalyse. Pages 114-121 in Einführung in die qualitative Sozialforschung. Eine Anleitung zu qualitativem Denken. 6, überarb Auflage. Beltz Verlag, Weinheim, Germany.

Meining, S., H. Puhlmann, P. Hartmann, R. Hoch, N. Augustin, H. Delb, J. Grüner, R. John, M. Kautz, G. Seitz, J. Wussler, A. Albrecht, H.-G. Michiels, and U. Kohnle. 2019. Waldzustandsbericht 2019 für Baden-Württemberg, Freiburg, Germany. Forstliche Versuchs-und Forschungsanstalt Baden-Württemberg, Freiburg, Germany.

Milad, M., H. Schaich, and W. Konold. 2013. How is adaptation to climate change reflected in current practice of forest management and conservation? A case study from Germany. Biodiversity and Conservation 22(5):1181-1202. https://doi. org/10.1007/s10531-012-0337-8

Millenium Ecosystem Assessment (MA). 2005. Ecosystems and human well-being - a framework for assessment. J. Alcamo, N. J. Ash, C. Butler, B. Callicott, J. C. Carpenter, S. Castilla, P. Chambers, R. Chopra, K. Cropper, A. Daily, G. Dasgupta, T. de Groot, R. Dietz, A. K. Duraiappah, M. Gadgil, K. Hamilton, R. Hassan, E. F. Lambin, L. Lebel, R. Leemans, L. Jiyuan, J.-P. Malingreau, R. M. May, A. F. McCalla, N. McMichael, T. A. J. Moldan, B. Mooney, H. Naeem, S. Nelson, G. C. Wen-Yuan, I. Noble, O. Zhiyun, S. Pagiola, D. Pauly, S. Percy, P. Pingali, R. Prescott-Allen, W. Reid, T. Ricketts, C. Samber, R. Scholes, H. Simons, F. Toth, J. Turpie, R. T. Watson, T. Wilbanks, M. Williams, S. Wood, Z. Shidong, and M. Zurek, editors. Island, Washington, D.C., USA.

Morin, X., L. Fahse, M. Scherer-Lorenzen, and H. Bugmann. 2011. Tree species richness promotes productivity in temperate forests through strong complementarity between species. Ecology Letters 14(12):1211-1219. https://doi.org/10.1111/j.1461-0248.2011.01691. $\underline{x}$

Nadrowski, K., C. Wirth, and M. Scherer-Lorenzen. 2010. Is forest diversity driving ecosystem function and service? Current Opinion in Environmental Sustainability 2(1-2):75-79. https:// doi.org/10.1016/j.cosust.2010.02.003

Nationalpark Schwarzwald. [date unknown]. Lage \& Zonierung. Nationalpark Schwarzwald, Seebach, Germany. [online] URL: https://www.nationalpark-schwarzwald.de/de/nationalpark/lagezonierung

Niedermann-Meier, S., M. Mordini, R. Bütler, and P. Rotach. 2010. Habitatbäume im Wirtschaftswald: ökologisches Potenzial und finanzielle Folgen für den Betrieb. Schweizerische Zeitschrift fur Forstwesen 161(10):391-400.

Paquette, A., and C. Messier. 2011. The effect of biodiversity on tree productivity: from temperate to boreal forests. Global 
Ecology and Biogeography 20(1):170-180. https://doi.org/10.1111/ j.1466-8238.2010.00592.x

Pascual, U., P. Balvanera, S. Díaz, G. Pataki, E. Roth, M. Stenseke, R. T. Watson, E. Başak Dessane, M. Islar, E. Kelemen, V. Maris, M. Quaas, S. M. Subramanian, H. Wittmer, A. Adlan, S. E. Ahn, Y. S. Al-Hafedh, E. Amankwah, S. T. Asah, P. Berry, A. Bilgin, S. J. Breslow, C. Bullock, D. Cáceres, H. Daly-Hassen, E. Figueroa, C. D. Golden, E. Gómez-Baggethun, D. GonzálezJiménez, J. Houdet, H. Keune, R. Kumar, K. Ma, P. H. May, A. Mead, P. O'Farrell, R. Pandit, W. Pengue, R. Pichis-Madruga, F. Popa, S. Preston, D. Pacheco-Balanza, H. Saarikoski, B. B. Strassburg, M. van den Belt, M. Verma, F. Wickson, and N. Yagi. 2017. Valuing nature's contributions to people: the IPBES approach. Current Opinion in Environmental Sustainability 26-27:7-16. https://doi.org/10.1016/j.cosust.2016.12.006

Pastowski, S. 2004. Messung der Dienstleistungsqualität in komplexen Marktstrukturen. Deutscher Universitats-Verlag/ GWV Fachverlage GmbH, Wiesbaden, Germany. https://doi. org/10.1007/978-3-322-81768-6

Peterson, G., C. R. Allen, and C. S. Holling. 1998. Ecological resilience, biodiversity, and scale. Ecosystems 1(1):6-18. https:// doi.org/10.1007/s100219900002

Petráš, R., J. Mecko, M. Bošel'a, and V. Šebeň. 2016. Wood quality and value production in mixed fir-spruce-beech stands: long-term research in the Western Carpathians. Forestry Journal 62 (2):98-104.

Plieninger, T., S. Dijks, E. Oteros-Rozas, and C. Bieling. 2013. Assessing, mapping, and quantifying cultural ecosystem services at community level. Land Use Policy 33:118-129. https://doi. org/10.1016/j.landusepol.2012.12.013

Polley, H., P. Henning, F. Kroiher, A. Marks, T. Riedel, U. Schmidt, F. Schwitzgebel, and T. Stauber. 2014. Der Wald in Deutschland. Ausgewählte Ergebnisse der dritten Bundeswaldinventur.

Pretzsch, H. 2013. Facilitation and competition in mixed-species forests analyzed along an ecological gradient. Nova Acta Leopold 114(391):159-174.

Pretzsch, H., T. Rötzer, R. Matyssek, T. E. E. Grams, K. H. Häberle, K. Pritsch, R. Kerner, and J. C. Munch. 2014. Mixed Norway spruce (Picea abies [L.] Karst) and European beech (Fagus sylvatica [L.]) stands under drought: from reaction pattern to mechanism. Trees 28(5):1305-1321. https://doi.org/10.1007/ $\underline{\text { s00468-014-1035-9 }}$

Rapport, D. J. 1995. Ecosystem health: more than a metaphor? Environmental Values 4(4):287-309. https://doi.org/10.3197/096327195776679439

Reed, M. S., A. Graves, N. Dandy, H. Posthumus, K. Hubacek, J. Morris, C. Prell, C. H. Quinn, and L. C. Stringer. 2009. Who's in and why? A typology of stakeholder analysis methods for natural resource management. Journal of Environmental Management 90(5):1933-1949. https://doi.org/10.1016/j. jenvman.2009.01.001

Ribe, R. G. 1989. The aesthetics of forestry: what has empirical preference research taught us? Environmental Management 13 (1):55-74. https://doi.org/10.1007/bf01867587
Rosenkranz, L. 2018. Produktionswert der Forstwirtschaft leicht rückläudig. Holz-Zentralblatt 17:383.

Rowley, J. 2012. Conducting research interviews. Management Research Review 35(3-4):260-271. https://doi.org/10.1108/0140$\underline{9171211210154}$

Schutzgemeinschaft Deutscher Wald (SDW). 2019. Der Wald in Baden-Württemberg. SDW, Stuttgart, Germany. [online] URL: https://www.sdw-bw.de/waldwissen/der-wald-in-baden-wuerttemberg/ index.html

Schwarz, J. A., and J. Bauhus. 2019. Benefits of mixtures on growth performance of silver fir (Abies alba) and European beech (Fagus sylvatica) increase with tree size without reducing drought tolerance. Frontiers in Forests and Global Change 2:79. https:// doi.org/10.3389/ffgc.2019.00079

Schwarzwald Tourismus GmbH. 2020. Neuer Rekord für den Tourismus. Schwarzwald Tourismus GmbH, Freiburg, Germany. [online] URL: https://www.schwarzwald-tourismus.info/presse/ aktuelle-presseinfos/weitere-meldungen/neuer-rekord-fuer-dentourismus\#: : text=Neuer

Schwarzwaldverein e.V. [date unknown]. Schwarzwaldverein: Organisation. Schwarzwaldverein e.V., Freiburg, Germany. [online] URL: https://www.schwarzwaldverein.de/schwarzwaldverein/ organisation/

Sohn, J. A., S. Saha, and J. Bauhus. 2016. Potential of forest thinning to mitigate drought stress: a meta-analysis. Forest Ecology and Management 380:261-273. https://doi.org/10.1016/ j.foreco.2016.07.046

Sousa-Silva, R., B. Verbist, Â. Lomba, P. Valent, M. Suškevičs, O. Picard, M. A. Hoogstra-Klein, V. C. Cosofret, L. Bouriaud, Q. Ponette, K. Verheyen, and B. Muys. 2018. Adapting forest management to climate change in Europe: linking perceptions to adaptive responses. Forest Policy and Economics 90:22-30. https://doi.org/10.1016/j.forpol.2018.01.004

Sprauer, S., and J. Nagel. 2015. Aboveground productivity of pure and mixed Norway spruce and European beech stands. European Journal of Forest Research 134(5):781-792. https://doi. org/10.1007/s10342-015-0889-8

Stadt Freiburg. 2013. Freiburg, Städtisches Forstamt. Stadt Freiburg, Germany. [online] URL: https://www.freiburg.de/ $\mathrm{pb} / 235024 . \mathrm{html}$

Strauss, A. L. 1987. Codes and coding. Pages 55-81 in Qualitative analysis for social scientists. Cambridge University Press, Cambridge, UK. https://doi.org/10.1017/CBO9780511557842

Tauro, A., E. Gómez-Baggethun, E. García-Frapolli, E. Lazos Chavero, and P. Balvanera. 2018. Unraveling heterogeneity in the importance of ecosystem services: individual views of smallholders. Ecology and Society 23(4):11. https://doi. org/10.5751/ES-10457-230411

Thompson, I., B. Mackey, S. McNulty, and A. Mosseler. 2009. Forest resilience, biodiversity, and climate change. Secretariat of the Convention on Biological Diversity, Montréal, Québec, Canada. 
Thünen Institut. 2012. Dritte Bundeswaldinventur - Ergebnisdatenbank. Thünen-Institut, Braunschweig, Germany. [online] URL: https:// bwi.info

Thünen Institute. 2019. Economic accounts for forestry. ThünenInstitut, Braunschweig, Germany. [online] URL: https://www. thuenen.de/en/wf/projects/economic-accounts/

Thurm, E. A., and H. Pretzsch. 2016. Improved productivity and modified tree morphology of mixed versus pure stands of European beech (Fagus sylvatica) and Douglas-fir (Pseudotsuga menziesii) with increasing precipitation and age. Annals of Forest Science 73(4):1047-1061. https://doi.org/10.1007/s13595-016-0588-8

Tost, H., M. Reichert, U. Braun, I. Reinhard, R. Peters, S. Lautenbach, A. Hoell, E. Schwarz, U. Ebner-Priemer, A. Zipf, and A. Meyer-Lindenberg. 2019. Neural correlates of individual differences in affective benefit of real-life urban green space exposure. Nature Neuroscience 22(9):1389-1393. https://doi. org/10.1038/s41593-019-0451-y

Tzoulas, K., K. Korpela, S. Venn, V. Yli-Pelkonen, A. Kaźmierczak, J. Niemela, and P. James. 2007. Promoting ecosystem and human health in urban areas using green infrastructure: a literature review. Landscape and Urban Planning 81(3):167-178.

United Nations. 2015. General Assembly: transforming our world: the 2030 Agenda for Sustainable Developement. United Nations, New York, New York, USA.

Van Kamp, I., K. Leidelmeijer, G. Marsman, and A. De Hollander. 2003. Urban environmental quality and human wellbeing towards a conceptual framework and demarcation of concepts; a literature study. Landscape and Urban Planning 65 (1-2):5-18.

VERBI Software. 2017. MAXQDA Analytics Pro 2018. Consult. Sozialforschung GmbH, Berlin, Germany.

Vilà, M., J. Vayreda, L. Comas, J. J. Ibáñez, T. Mata, and B. Obón. 2007. Species richness and wood production: a positive association in Mediterranean forests. Ecology Letters 10(3):241250. https://doi.org/10.1111/j.1461-0248.2007.01016.x 


\section{Appendix 1}

Table A1.1: Interview question

Below is a list of ecosystem services of the different four categories (according to the MEA classification). a) Please select one ecosystem service in each of the four categories that is most important to you (Priority). b) Please justify your choice. c) In which forest type are the ecosystem services you prioritized better provided and why?

$\begin{array}{ll}\begin{array}{l}\text { Ecosystem service } \\ \text { category }\end{array} & \text { Ecosystem services provided by forests } \\ & \\ \text { Provisioning } & \text { Timber yield } \\ & \text { Biomass productivity } \\ & \text { Profitability } \\ & \text { Hunting potential } \\ & \text { Non-wood forest products } \\ & \\ \text { Mushrooms, fruits, wild garlic and forest honey and other } \\ \text { non-wood products } \\ \text { Recreation activities, spiritual experiences } \\ \text { Education } \\ \text { Tourism } \\ \text { Observation of wild life and plants } \\ \\ \text { Air pollution controll } \\ \text { Water retention and storage } \\ \text { Soil and erosion protection } \\ \text { Carbon storage capacity } \\ \text { Regulating }\end{array}$

Priority Selected forest type with a preferred/ better provision of ecosystem services

Beech-fir Fir forests Beech Don't

mixed forests forests know




\section{Biodiversity}

Resilience to storm events

Tolerance to dry periods

Protection against diseases and tree pests (e.g. by in-

sects, fungi, etc.) 